•研究报告・

\title{
西双版纳种子植物物种多样性的垂直格局及机制
}

\author{
徐 翔 张化永 ${ }^{*}$ 谢 婷 孙青青 田永兰 \\ (华北电力大学工程生态学与非线性科学研究中心, 北京 102206)
}

\begin{abstract}
摘要: 物种多样性海拔分布格局及其形成机制的研究是生物地理学和宏观生态学的重要议题之一。本文利用西双 版纳植物专著资料, 结合高分辨率的地形和气候等数据, 探讨了面积、边界限制和现代气候对西双版纳野生种子 植物物种丰富度及物种密度海拔分布格局的影响。结果表明: (1)物种丰富度呈单峰分布格局, 面积(81.9\%)、边界 限制(17.5\%)和气候(60.0-69.3\%)都不同程度地解释了物种丰富度的单峰格局; (2)利用幂函数种一面积关系计算的 物种密度沿海拔大致呈减小的分布趋势, 气候的解释率降低为 $32.6-40.6 \%$, 与边界限制无显著相关关系; (3)利用 等面积高度带划分得到的物种密度沿海拔呈单峰变化趋势, 物种密度与边界限制无显著相关性, 但气候对物种密 度的解释率为81.6-89.9\%。研究结果有助于准确全面地理解物种多样性的海拔分布格局及其成因机制, 为西双版 纳生物多样性保护提供理论支撑和实践指导。
\end{abstract}

关键词: 物种丰富度; 物种密度; 种-面积关系; 中域效应; 海拔

\section{Elevational pattern of seed plant diversity in Xishuangbanna and its me- chanisms}

\author{
Xiang Xu, Huayong Zhang*, Ting Xie, Qingqing Sun, Yonglan Tian \\ Research Center for Engineering Ecology and Nonlinear Science, North China Electric Power University, Beijing \\ 102206
}

\begin{abstract}
The mechanisms underlying elevational patterns of species diversity remain one of the most important questions in biogeography and macroecology. We studied the effects of area, mid-domain effect (MDE) and contemporary climate on elevational patterns in species richness and species density for native seed plants in Xishuangbanna, for which we used plant monograph, digital elevation model, and large-scale climatic data. We found that: (1) area, MDE, and climate explained 81.9\%, 17.5\%, and $60.0-69.3 \%$ of the unimodal pattern in species richness; (2) when species richness calculated using the species-area hypothesis showed a decreasing pattern along the elevational gradient. Moreover, richness was not correlated to MDE and the explanatory power of climate decreased to 32.6-40.6\%; (3) species richness calculated using equal-area elevational bands showed a hump-shaped pattern but was not correlated to MDE; the explanatory power of climate was 81.6-89.9\%. Our results provides comprehensive insights into the theoretical mechanisms underlying elevational patterns in species diversity and also provide practical guidance for the biodiversity conservation in Xishuangbanna.
\end{abstract}

Key words: species richness; species density; species-area relationship; mid-domain effect; elevation

近年来, 物种丰富度沿海拔梯度的分布格局受 到越来越多的关注(郑智等, 2014; Xu et al, 2017)。物 种丰富度随海拔的上升呈 4 种变化趋势, 其中单峰 分布格局最为普遍(Rahbek, 1997, 2005)。研究人员
从面积、中域效应和现代气候等多个角度对物种丰 富度的海拔梯度格局进行了解释(Currie \& Paquin, 1987; Colwell \& Hurtt, 1994; Karger et al, 2011; 刘 开明等, 2017)。其中, 物种丰富度随栖息地面积的

收稿日期: 2018-03-08; 接受日期: 2018-05-26

基金项目: 国家水体污染控制与治理科技重大专项(2017ZX07101001-01；2015ZX07203-011；2015ZX07204-007; 2009ZX07210-009)和中央高校基本科 研业务费专项资金(2017MS065)。

* 通讯作者 Author for correspondence. E-mail: bjecology@gmail.com 
增加而增加的现象, 被认为是“生态学中少有的几 个真正的定理之一” (Lomolino, 2001; 李巧燕和王 襄平, 2013), 被描述为种-面积关系理论(speciesarea relationship) (Arrhenius, 1921)。中域效应 (mid-domain effect, MDE)模型认为区域的边界会对 物种的分布造成限制, 即物种的分布不能超出区域 的边界, 这就造成区域中心物种的分布区重叠程度 较大而边界附近重叠程度较小, 在没有环境梯度和 物种随机分布的情况下, 会形成物种丰富度的单峰 分布格局(Colwell \& Lees, 2000)。已有很多研究表 明MDE模型能很好地解释物种丰富度的海拔分布 格局(Colwell \& Hurtt, 1994; Sanders, 2002; Grytnes et al, 2010), 但关于MDE的作用目前仍存在较多争 议(Colwell et al, 2004)。

气候对物种丰富度空间分布格局的重要影响 已得到广泛认可, 其中以气候为基础的能量假说受 到的关注最多(O’Brien, 1998; 王志恒等, 2009a)。常 见的能量假说有生态学代谢假说(metabolic theory of ecology, MTE)、环境能量假说(ambient energy hypothesis)、水分-能量动态假说(water-energy dynamic hypothesis)、寒冷忍耐假说(freezing tolerance hypothesis)和生产力假说(productivity hypothesis) (王志 恒等, 2009a)。基于个体新陈代谢速率与体形大小及 绝对温度关系提出的生态学代谢假说预测物种丰 富度的对数与绝对温度的倒数呈线性关系, 且斜率 介于-0.70至-0.60之间(Gillooly et al, 2001; Allen et al, 2002; Brown et al, 2004; 王志恒等, 2009b)。该假 说通常采用年均温(mean annual temperature)和潜在 蒸散量(potential evapotranspiration, PET)等指标来 衡量某地区热量动能的多少(Currie, 1991)。基于水 分对生物体能量利用过程的影响提出的水分-能量 动态假说认为物种多样性的大尺度格局由热量动 能和液态水分共同决定, 通常用年均温或PET来衡 量热量动能, 用年降水量(mean annual precipitation) 来衡量液态水分(O’Brien, 1993; Hawkins et al, 2003; 王志恒等, 2009a)。寒冷忍耐假说认为冬季低温限制 物种生存, 从而减少物种多样性(Hawkins, 2001), 通常用最冷月最低温(minimum temperature of coldest month)来衡量。生产力假说认为能量在不同营养 级之间的流动影响物种多样性的分布(Clarke \& Gaston, 2006; Evans et al, 2006), 通常用净初级生产
力 (net primary productivity, NPP) 或实际蒸散量 (actual evapotranspiration, AET)来衡量一个地区的 能量(Currie \& Paquin, 1987; Adams \& Woodward, 1989; Nogués-Bravo et al, 2008; 刘庆福等, 2015)。

面积和气候因素都随着海拔的变化而变化, 中 域效应主要制约山脚和山顶物种的分布范围, 因此 植物物种丰富度的垂直梯度格局受面积、中域效应 和现代气候的共同制约(池秀莲和唐志尧, 2011), 而 且面积对植物物种丰富度的显著影响可能会掩盖 中域效应和现代气候对植物物种丰富度的重要影 响。因此, 有必要剔除面积的影响探索植物物种多 样性(消除面积影响后的物种丰富度, 即物种密度) 的垂直分布格局及其形成机制(Wang et al, 2007; Pouteau et al, 2015)。

目前, 计算物种密度的方法有多种, 其中应用 最广泛的可归纳为两种: (1)种-面积关系理论(王志 恒等, 2004b; 冯建孟等, 2006); (2)将海拔梯度划分 为数个等面积的高度带, 每个高度带上的物种个数 被视作去除了面积影响的物种丰富度, 即物种密度 (Bachman et al, 2004)。越来越多的研究采用上述两 种方法探索物种密度的垂直梯度格局及其形成机 制(朱源等, 2007; 和霞等, 2011), 但是缺少在同一 个区域同时采用上述两种方法揭示物种密度的海 拔梯度格局并探索物种密度的不同计算方法对其 格局影响的研究。

西双版纳是国际上生物多样性保护的关键和 热点地区之一(Myers, 1988; 朱华等, 2015), 拥有我 国热带地区保存面积最大的热带森林(即我国生物 多样性最丰富的生态系统之一) (朱华, 2007)。目前对 西双版纳植物的研究主要集中在植物群落组成、群 落特征和森林植被分类(李冬等, 2006; 朱华, 2006; 兰国玉等, 2008)等方面, 而对物种丰富度和物种密 度的海拔梯度格局及其形成机制的研究较少(刘洋 等, 2007)。鉴于此, 本文通过收集《云南西双版纳 野生种子植物》 (朱华和闰丽春, 2012)提供的物种分 布信息, 结合数字高程模型(DEM)、全球气候数据 库(WorldClim)和统计分析方法, 研究了西双版纳野 生种子植物的物种丰富度和物种密度的垂直分布 格局, 从面积、中域效应和现代气候的角度探索了 其形成机制, 并系统比较了不同计算方法对物种密 度的垂直分布格局及其形成机制解释的影响。 


\section{材料与方法}

\section{1 研究地点}

西双版纳 $\left(21^{\circ} 09^{\prime}-22^{\circ} 36^{\prime} \mathrm{N}, 9^{\circ} 58^{\prime}-101^{\circ} 50^{\prime} \mathrm{E}\right)$ 位于云南南部，其西、北、东三面与滇西南山原、 山地相连, 属于横断山系南端无量山脉和怒山山脉 的余脉山原、山地地区(图1)。西双版纳占地面积 $19,690 \mathrm{~km}^{2}$, 其四周为山地, 中部主要为山原, 也分 布着许多盆地、低山和低丘, 呈四周高中部低的地 形，平均海拔约 $1,100 \mathrm{~m}$ 。南腊河和澜沧江交汇处海 拔最低, 为 $414 \mathrm{~m}$, 澜沧江西岸的华竹梁子海拔最 高, 为2,428 $\mathrm{m}$ 。由于受印度洋季风的影响, 西双版 纳属于西部型热带季风气候, 气候随地形和海拔的 变化十分明显(朱华和间丽春，2012)。年均温为 $13.6-23.7^{\circ} \mathrm{C}$, 年降水存在干、湿季节分明和东湿西 干的特点，年均降水量1,214-1,817 $\mathrm{mm}$, 其中 $80 \%$ 以上集中在雨季(5-10月)。西双版纳的水平地带性 植被为热带季节性雨林和季雨林, 垂向地带性植被 为热带山地常绿阔叶林(又称季风常绿阔叶林)、热 带山地雨林和热带季节性湿润林(朱华和问丽春, 2012)。与气候和地带性植被类型相关的土壤类型包 括海拔600-1,000 $\mathrm{m}$ 的热带雨林、季雨林砖红壤, 1,000-1,600 m的季风常绿阔叶林赤红壤, $1,600 \mathrm{~m}$ 以 上的山地红壤和在某些地方间隔分布的岩性土(朱 华和闩丽春, 2012)。

\section{2 物种的海拔分布信息}

植物物种的海拔分布信息来源于《云南西双版

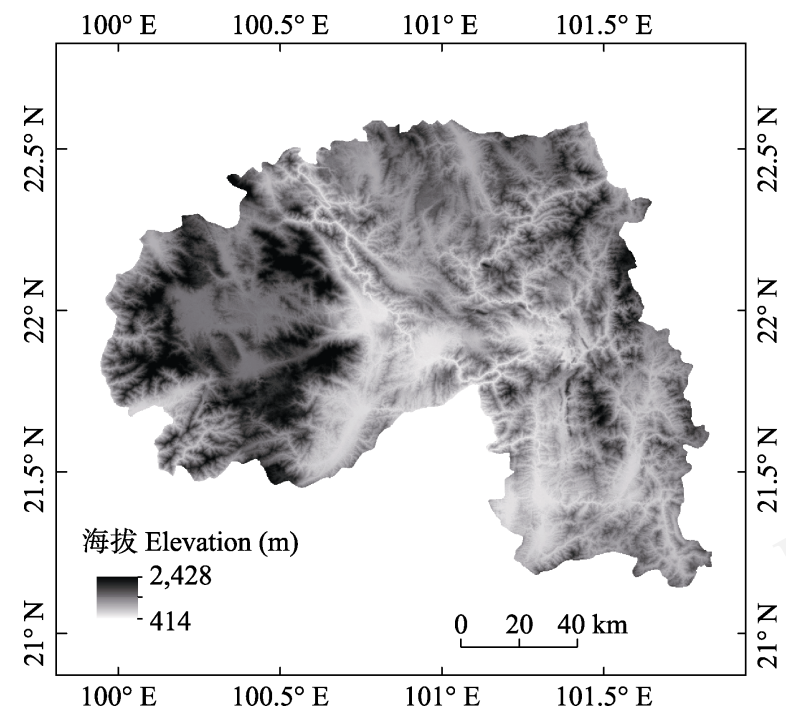

图1 西双版纳的地形分布图

Fig. 1 Topography distribution of Xishuangbanna
纳野生种子植物》(朱华和闵丽春, 2012)。经统计，该 专著提供了 173 科1,152属3,543种野生种子植物的 海拔分布范围。对其中只有单一海拔记录的 1,205 个物种，在该记录的基础上加减50 m估计该物种的 海拔分布上下限(Tang et al, 2014)。假设物种在其海 拔上下限范围之内连续分布(Acharya et al, 2011)。

\subsection{DEM、土地利用和气候数据}

DEM (http://gdex.cr.usgs.gov/gdex/)和土地利用 数 据 (Chen et al, 2014; 陈军等， 2017; http://glc30.tianditu.com/)的空间分辨率均为 $30 \mathrm{~m} \times$ $30 \mathrm{~m}$ 。西双版纳包含森林、灌木地、草地、耕地、 湿地、水体和人造地表7种土地利用类型，其中适宜 野生种子植物生长的栖息地为森林、灌木地和草地 (图2)。因此, 为准确计算西双版纳野生种子植物栖 息地的面积，去除耕地、湿地、水体和人造地表覆 盖的土地，只保留森林、灌木地和草地覆盖的像元 (共13,210 $\mathrm{km}^{2}$ )参与后续计算。采用WorldClim全球 气候数据集(Hijmans et al, 2005)提供的年平均气 温、年降水量和最冷月最低温数据。

\section{4 划分等海拔间隔的高度带}

我们以 $100 \mathrm{~m}$ 为间隔将西双版纳划分为 20 个高 度带(例如, 414-499 m, 500-599 m, ….. 2,200-2,299 $\mathrm{m}, 2,300-2,428 \mathrm{~m})$ 。统计每个高度带内野生种子植 物的物种个数, 记作物种丰富度。运用ArcGIS 10.3 提取 20 个高度带的年平均气温、年降水量、最冷月 最低温和AET值。

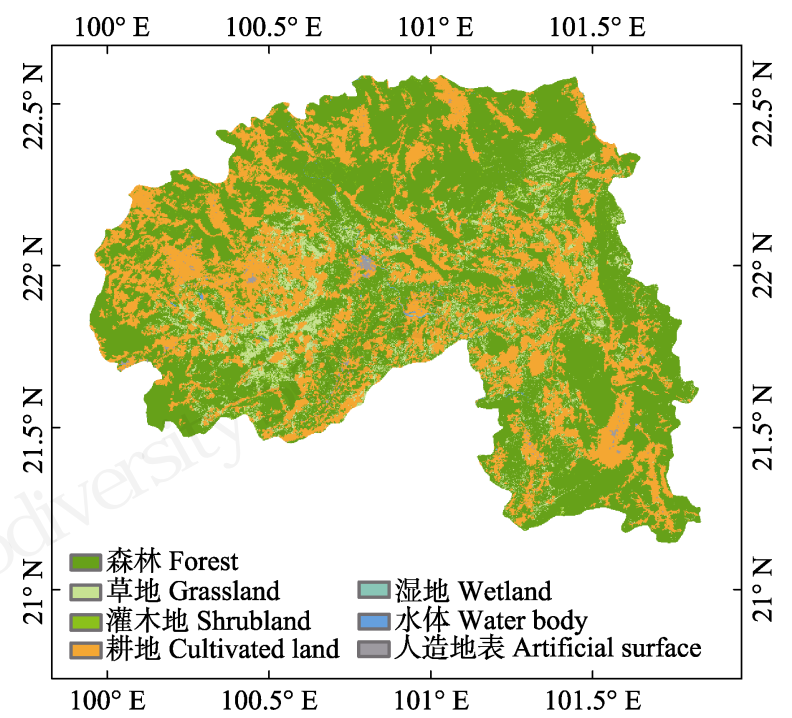

图2 西双版纳的土地利用类型分布图

Fig. 2 Land use distribution of Xishuangbanna 


\section{5 利用种-面积关系理论计算物种密度}

取样面积会显著影响该地区的物种丰富度 (Arrhenius, 1921), 为了消除面积的影响, 许多研究 采用种一面积关系理论计算物种密度(王志恒等, 2004b)。虽然种-面积关系理论已经得到生态学家的 广泛认同，但是该理论共有4种模型: $S / A 、 S / \log (A)$ 、 $\log (S) / A$ 和 $\log (S) / \log (A)$, 其中 $S$ 和 $A$ 分别是每 $100 \mathrm{~m}$ 高度带的物种丰富度和面积, 不同地区的最优模型 并不相同(Qian, 1998; McCain, 2007)。为了确定西双 版纳地区的最优种一面积关系模型, 对这 4 种模型分 别进行最小二乘法回归拟合分析，F检验显著 $(P<$ 0.05)且校正后赤池信息准则(adjusted Akaike information criterion, $\mathrm{AIC}_{\mathrm{C}}$ )最小的模型为最优模型。拟合 结果表明, 最优模型 (附录 1 ) 是 $\log (S) / \log (A)$, 即双 对数坐标系统的幕函数 $S=\mathrm{c} A^{\mathrm{z}}$, 其中 $\mathrm{z}$ 是斜率, $\mathrm{c}$ 是 物种密度, 它可解释西双版纳物种丰富度 $81.0 \%$ 的 变化。为了使物种密度与物种丰富度的数值大小具 有相同的数量级, 我们计算每 $100 \mathrm{~m}$ 高度带的物种 密度 $I=100 \times S / A^{\mathrm{Z}}$ 。

\section{6 划分等面积的高度带}

根据 Bachman 等 (2004) 提出的方法, 利用 ArcGIS产生 -0.5 到 0.5 的随机数, 并与 DEM的每个 像元相加, 从而使DEM的每个像元值成为拥有 1 位 小数的十进制数。对西双版纳参与计算的DEM像元 进行等面积高度带的划分, 即所有高度带的像元数 大致相等。本文将西双版纳划分为 20 个等面积的高 度带, 每个高度带的面积约为660 $\mathrm{km}^{2}$ (附录2)。统 计每个高度带上出现的物种个数, 记作物种密度 $I_{20}$ 。运用 ArcGIS提取每个等面积高度带的年平均气 温、年降水量、最冷月最低温和AET值。

\section{7 中域效应}

利用RangeModel模拟空间边界对物种分布限 制所引起的物种丰富度格局效应(Colwell, 2008)。根 据RangeModel提供的经验分布宽度模型, 将物种的 实际分布区在具有 “硬边界”的区域中随机摆放，物 种中心点根据分布宽度和几何限制在可能的范围 内随机生成。在不同高度带内统计落入物种的个数, 即为RangeModel模拟的物种丰富度。该模拟值主要 取决于高度带数量、参与计算的物种总数、物种的 实际分布宽度和物种的实际分布中心点。高度带的 数目越多, 每个高度带内的物种丰富度相对越小。 随机采样运算 1,000 次后计算平均值作为中域效应
的模拟值。

\section{8 统计分析}

首先, 运用一次和二次拟合, 分析因变量(物种 丰富度和物种密度 $I 、 I_{20}$ ) 和解释因子(中域效应模拟 值、年均温、年降水量、最冷月最低温和实际蒸散 量)之间的二元关系, $F$ 检验显著 $(P<0.05)$ 且样本大 小矫正过的赤池信息量准则最小的模型为各解释 因子的最优拟合模型。其次, 考虑到物种分布数据 和气候数据普遍存在显著的空间自相关，而这通常 会降低样本的独立性，从而增加显著性检验时犯第 一类错误的概率，倾向于得到更显著的结果 (Diniz-Filho et al, 2003)。因此, 本文采用Moran's I 指数比较因变量和模型残差在不同距离上的空间 自相关，评估空间自相关对本文回归分析结果的影 响。Moran’s I的取值范围在-1到1之间，正值表示正 相关，负值表示负相关，0则表示空间格局是随机 的。最后，为了解决各解释因子之间的共线性问题， 本文采用方差分离(variation partitioning)方法把因 变量全部能够被解释的方差分离为各解释因子的 共同作用部分和独立作用部分，其中独立作用部分 度量了某个解释因子的相对重要性(Borcard et a1, 1992)。本文的统计分析在 R 软件中(程序包AICcmodavg、MuMIn和ncf)完成。

\section{9 空缺分析}

空缺分析(GAP analysis)是指将多样性保护的 热点地区与现有的生物多样性保护网络的空间信 息进行叠加，找出那些没有被保护网络覆盖的多样 性热点地区，从而在日后的管理实践中通过新建保 护区等方式来填补(李迪强和宋延龄, 2000)。本文基 于西双版纳野生种子植物的物种丰富度数据, 采用 筛除算法(Dobson, 1997; 张殷波等, 2015)确定西双 版纳植物多样性保护的热点地区，其原理是找出包 含所有物种的最少个数的等间隔海拔段: 首先选取 物种丰富度最高的海拔段, 然后将该海拔段中包含 的物种从总名录中剔除，再选取剩余物种丰富度排 序最高的海拔段, 重复以上过程直至选择的诸海拔 段中包含西双版纳的所有野生种子植物。本文将包 含 $90 \%$ 以上物种的海拔段定位为西双版纳植物多样 性的热点地区(Kati et al, 2004; Zhang et al, 2015)。随 后，本文搜集了西双版纳现有自然保护区的图层数 据，包括2个国家级自然保护区 (西双版纳国家级自 然保护区和纳板河流域国家级自然保护区，其中， 
西双版纳国家级自然保护区包括曼稿、预养、预仑、 预腊和尚勇 5 个子保护区)和 2 个州级自然保护区(布 龙州级自然保护区和易武州级自然保护区)。最后, 本文将西双版纳的多样性热点地区和现有的自然 保护区数据进行空间叠加, 识别保护空白地区(闻 丞等, 2015)。

\section{2 结果}

\section{1 物种丰富度及其解释因子的海拔梯度格局}

物种丰富度随海拔的上升呈先增后减的单峰 格局, 在海拔800-900 m范围内达到最高, 有 1,876 个物种，占西双版纳野生种子植物的 $52.9 \%$ (图3)。 在低海拔区即 $900 \mathrm{~m}$ 以下, 物种丰富度随海拔的平 均垂直递增率约为 452 种 $/ 100 \mathrm{~m}\left(n=5, R^{2}=0.945\right.$, $P<0.01)$ 。在高海拔区 $900-2,100 \mathrm{~m}$ 范围内, 物种丰 富度随海拔的平均垂直递减率约为 172 种 $/ 100 \mathrm{~m}$ $\left(n=12, R^{2}=0.988, P<0.001\right)$ 。

随着海拔的升高, 每100 m高度带的面积先增 后减，峰值出现在海拔1,100-1,200 m (附录3)。海拔 梯度上, 中域效应模拟的物种丰富度随海拔上升呈 现先增后减的单峰格局, 在海拔1,400-1,500 m内达 到最高, 有 1,153 个物种, 占西双版纳野生种子植物 的 $32.5 \%$ 。年均温和最冷月最低温随海拔的升高呈 单调递减格局, 垂直递减率分别约为 $0.5^{\circ} \mathrm{C} / 100 \mathrm{~m}(\mathrm{n}$ $\left.=20, R^{2}=0.998, P<0.001\right)$ 和 $0.6^{\circ} \mathrm{C} / 100 \mathrm{~m}(n=20$, $\left.R^{2}=0.997, P<0.001\right)$ 。年降水量在 $600 \mathrm{~m}$ 以下随海 拔升高而减少, 之后随海拔升高而增大, 在 1,800-2,000 m范围内又随海拔升高而减小, 之后随 海拔升高而增大。实际蒸散量随海拔的升高整体上

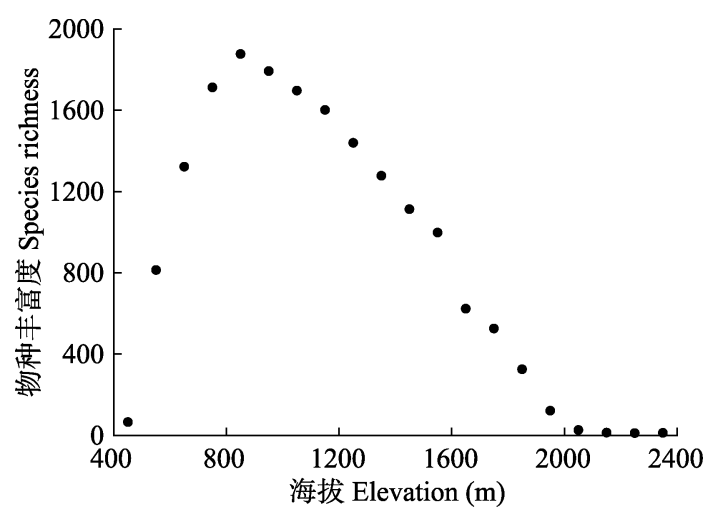

图3西双版纳种子植物物种丰富度的垂直分布格局 Fig. 3 Elevational pattern of species richness for seed plants in Xishuangbanna
呈现单调递减格局。

\section{2 物种多样性与解释因子的关系}

中域效应模拟值的一次方程可解释物种丰富 度17.5\%的变化, 年均温、年降水量、最冷月最低温 和实际蒸散量的二次方程可分别解释物种丰富度 $66.3 \% 、 64.5 \% 、 69.3 \%$ 和 $60.0 \%$ 的变化(图4，附录 $4-5)$ 。在适宜温度 $\left(\right.$ 年均温 $21.5^{\circ} \mathrm{C}$, 最冷月最低温 $8.8^{\circ} \mathrm{C}$ )和适宜降水(年降水量 $1,489 \mathrm{~mm}$, 实际蒸散量 $1,015 \mathrm{~mm}$ ) 情况下，野生种子植物的物种个数最多。 利用种一面积关系计算的物种密度随海拔的上升大 致呈现减小的趋势，中间伴随多次波动(附录6)。中 域效应模拟值与物种密度 $I$ 无显著相关关系, 年降 水量的一次方程以及年均温、最冷月最低温和实际 蒸散量的二次方程可分别解释物种密度 $I$ 变化的 $32.6 \% 、 39.5 \% 、 40.6 \%$ 和 $36.7 \%$ (附录7)。物种密度 $I_{20}$ 随海拔的上升呈现先增后减的单峰分布格局, 在 海拔848.6-907.6 m内达到最高，有1,934个物种，占 西双版纳野生种子植物的 $54.6 \%$ (附录8)。中域效应 模拟值与物种密度 $I_{20}$ 无显著相关关系，年均温、年 降水量、最冷月最低温和实际蒸散量的二次方程可 分别解释物种密度 $87.3 \%$ 、89.9\%、88.3\%和 $81.6 \%$ 的 变化(附录9)。

\section{3 空间自相关}

物种丰富度和物种密度 $I 、 I_{20}$ 的Moran’s $I$ 指数在 较短的距离上呈显著正相关，而模型残差的空间自 相关显著减弱(附录10-12)。这表明所构建的模型可 靠, 能够很好地解释西双版纳野生种子植物物种丰 富度和物种密度的垂直分布格局，模型的残差主要 是一些随机变化和取样误差。

\section{4 空缺分析}

采用Dobson篎除算法鉴别得到西双版纳的7个 等间隔海拔段为种子植物多样性保护的热点地区, 按篮选次序依次为 800-900 $\mathrm{m}$ 、1,300-1,400 m、 600-700 m、1,000-1,100 m、1,500-1,600 m、1,7001,800 m和1,100-1,200 m (图5a)。这些热点地区累计 包含 3,262 个物种, 占西双版纳野生种子植物的 92.07\%; 累计包含面积7,386.79 $\mathrm{km}^{2}$ ，占西双版纳 总面积的 $56.20 \%$ (图5b)。

将这7个热点海拔段和西双版纳现有的自然保 护区图层叠加，各海拔段均被自然保护区不同程度 地覆盖，其中海拔段1,000-1,100 m和1,100-1,200 m 被自然保护区覆盖的面积比例最大，分别为 $36.20 \%$ 

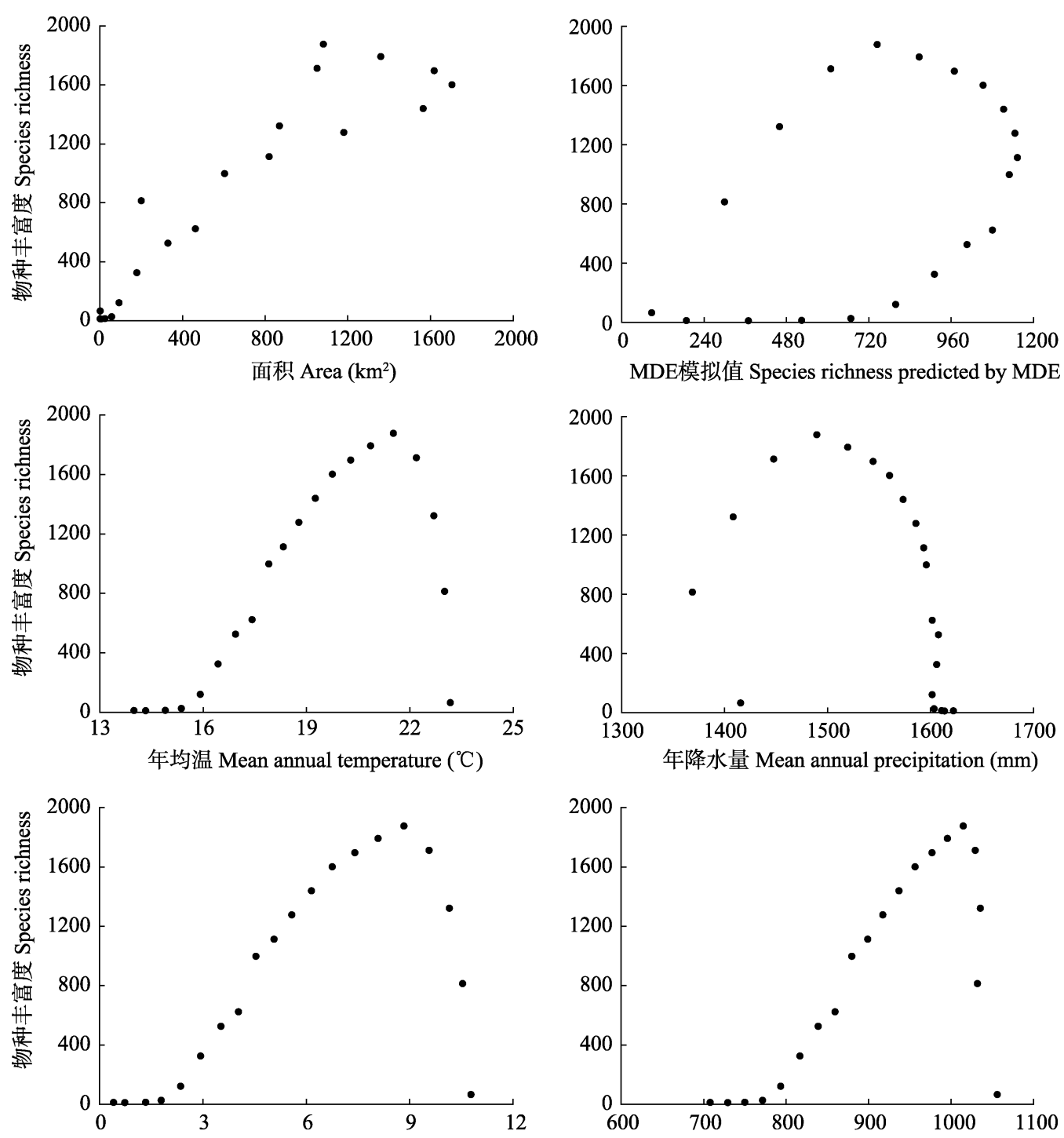

最冷月最低温 Minimum temperature of coldest month $\left({ }^{\circ} \mathrm{C}\right)$

实际蒸散量 Actual evapotranspiration $(\mathrm{mm})$

图4 西双版纳种子植物物种丰富度与面积、中域效应(MDE)模拟值、年均温、年降水量、最冷月最低温和实际蒸散量的关系 Fig. 4 Relationship between species richness of seed plants and area, species richness predicted by mid-domain effect (MDE), mean annual temperature, mean annual precipitation, minimum temperature of coldest month and actual evapotranspiration in Xishuangbanna
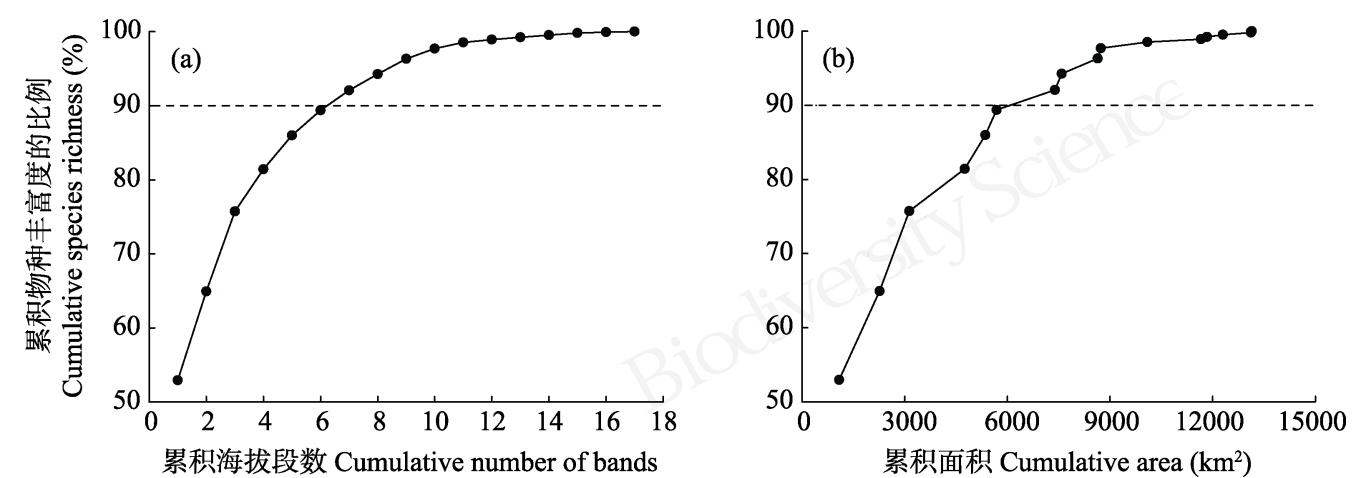

图5 基于篮除算法鉴别得到的西双版纳植物多样性热点地区累积物种数目的比例与累积海拔段数(a)和累积面积(b)的关系 Fig. 5 Relationship between cumulative species richness and cumulative number of bands (a), cumulative area (b) in plant diversity hotspots identified using the complementary algorithm in Xishuangbanna 


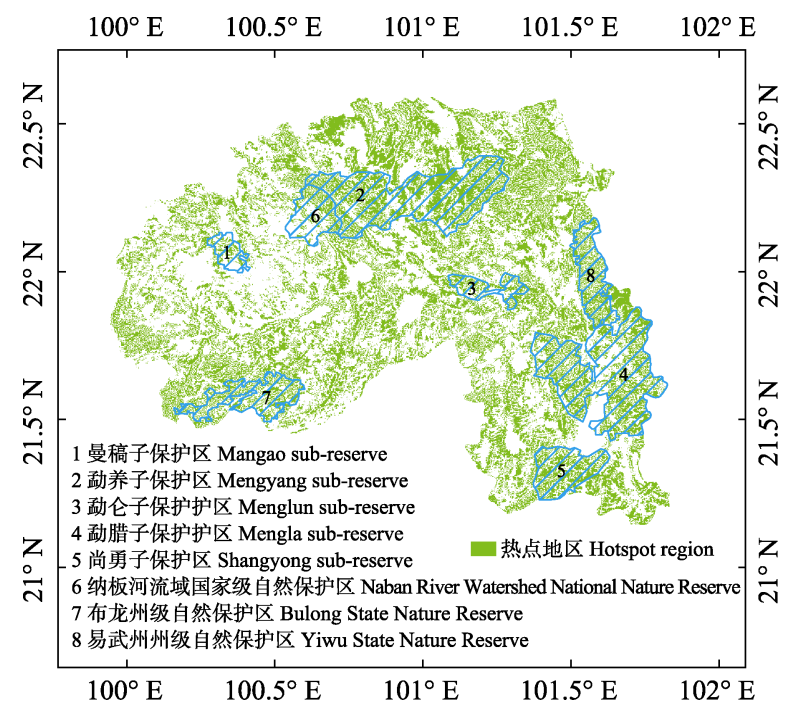

图6 基于篮除算法鉴别得到的西双版纳植物多样性热点地 区和自然保护区的空间关系

Fig. 6 Spatial relationship between plant diversity hotspots identified using the complementary algorithm and nature reserves in Xishuangbanna.

表1 西双版纳植物多样性热点地区和自然保护区的空间 关系

Table 1 Spatial regression between plant diversity hotspots and nature reserves in Xishuangbanna

\begin{tabular}{lll}
\hline $\begin{array}{l}\text { 热点地区海拔段 } \\
\begin{array}{l}\text { Hotspot elevational } \\
\text { band }(\mathrm{m})\end{array}\end{array}$ & $\begin{array}{l}\text { 保护区覆盖的热点地区 } \\
\text { Hotspot area covered } \\
\text { by nature reserves }\left(\mathrm{km}^{2}\right)\end{array}$ & $\begin{array}{l}\text { Percentage of } \\
\text { 比例 } \\
\text { area } \\
\text { reserves (\%) }\end{array}$ \\
\hline $800-900$ & 312.63 & 28.90 \\
$1,300-1,400$ & 303.45 & 25.70 \\
$600-700$ & 57.16 & 6.58 \\
$1,000-1,100$ & 585.83 & 36.20 \\
$1,500-1,600$ & 129.96 & 21.53 \\
$1,700-1,800$ & 61.78 & 18.76 \\
$1,100-1,200$ & 529.49 & 31.08 \\
合计 Total & $\mathbf{1 , 9 8 0 . 3 0}$ & $\mathbf{2 6 . 8 1}$ \\
\hline
\end{tabular}

和31.08\%; 海拔段600-700 m被覆盖的面积比例最 小, 为6.58\% (图6, 表1)。总体来说, 涵盖西双版纳 92.07\%野生种子植物的热点海拔段, 共有 $26.81 \%$ 的 面积被现有的自然保护区覆盖，其余73.19\%的面积 与自然保护区没有重叠, 为保护空白地区。这些保 护空白地区在西双版纳野生种子植物的保护工作 中需要引起更多的重视。

\section{3 讨论}

\section{1 西双版纳物种丰富度单峰格局的解释}

将西双版纳划分为等海拔间隔的高度带，每
$100 \mathrm{~m}$ 高度带上的野生种子植物物种丰富度随海拔 的上升呈现先增后减的单峰格局，且峰值出现在中 低海拔(800-900 m)处，这与国内外的许多研究结 果一致(王志恒等, 2004b; Rahbek, 2005; 冯建孟等, 2006; 刘洋等, 2007)。物种丰富度的海拔梯度格局 往往是由不同解释因子的共同影响形成的(池秀莲 和唐志尧，2011), 而西双版纳野生种子植物在海拔 800-900 m范围内最丰富，也反映了面积、边界限制 和现代气候的共同影响。

首先，植物群落的生态过渡带往往会导致物种 丰富度最大值的出现(Lomolino，2001; 冯晨光等, 2017), 而西双版纳海拔900 m附近正是热带季节雨 林和热带季雨林与热带山地常绿阔叶林或季风常 绿阔叶林的过渡地带(朱华和闰丽春，2012)。另外， 幂函数种-面积关系 $S=\mathrm{c} A^{\mathrm{z}}$ 对西双版纳野生种子植 物物种丰富度海拔分布格局的解释率为 $81.9 \%$, 表 明面积对物种丰富度的重要作用，这一结果与其他 山地研究相似(Bachman et al, 2004; Wang et al, 2007; 池秀莲和唐志尧, 2011)。但本研究还发现, 物种丰 富度最大值出现的海拔范围与面积最大值所处的 海拔区间(1,100-1,200 m) 并不吻合，这说明物种丰 富度并不只受面积的影响, 其他因素也影响物种丰 富度的大小。

其次, 我们的研究结果显示, 边界限制解释了 西双版纳野生种子植物物种丰富度 $17.5 \%$ 的垂直变 化，表明边界限制促进了该地区物种丰富度单峰格 局的形成。但是，本文还发现边界限制的解释率相 对较小, 这是由于边界限制对物种丰富度分布的作 用主要受到物种分布宽度的影响，对广域物种的影 响大于对狭域物种的影响(Jetz \& Rahbek, 2002)。而在 西双版纳近 $90 \%$ 的物种(3,176种)其海拔分布宽度小 于整个海拔梯度的一半(即 $1,000 \mathrm{~m})$ 。这与池秀莲和 唐志尧(2011)在秦岭太白山的研究结果相同。

最后，本研究发现年均温、年降水量、最冷月 最低温和实际蒸散量可分别解释西双版纳物种丰 富度海拔梯度格局66.3\%、64.5\%、69.3\%和60.0\%的 变化。这表明气候对物种丰富度有显著影响，也与 以往的研究结果一致(Woodward et al, 2004)。水分 和热量的共同作用影响着植物物种分布的格局 (Allen, 2002)。高温能加快物种的新陈代谢速率，从 而提高一个地区的物种形成速率，进而维持该地区 较高的物种丰富度水平(王志恒等，2009b)。通常表 
现为年降水量的液态水分在植物的生理活动中发 挥着至关重要的作用, 一方面是生物化学过程的重 要溶剂, 另一方面是光合和呼吸等许多生化反应的 重要反应物或产物; 同时, 液态水分的运动可为植 物吸收和运输营养物质提供动力, 显著影响植物的 能量利用过程(Hawkins \& DeVries, 2009)。中海拔是 水热组合最佳的区域, 提高了土壤的矿化速率, 为 更多物种的生存提供了更多的养分, 因而是物种最 丰富的区域。低海拔物种丰富度较低主要是人为干 扰形成的, 而在高海拔物种丰富度较低是因为温度 较低降低了养分的矿化速率。寒冷忍耐假说认为许 多物种由于不能忍受冬季的低温而无法生存 (Hawkins et al, 2003)。在高海拔区, 种子植物的物种 丰富度随着最冷月最低温的降低而显著减少, 支持 寒冷忍耐假说。西双版纳位于中国热带区域, 绝大 多数种子植物的祖先是从热带地区或是一些湿热 地区进化而来的，因此并不具备抵御寒冷的机制, 其分布受到环境低温的限制。

西双版纳山地种子植物的海拔分布数据库中 包含 1,205 个具有单一海拔分布记录的物种(例如多 年生草本狭叶沿阶草Ophiopogon stenophyllus分布 记录800 $\mathrm{m}$ 等)。为了探索插值方法对西双版纳山地 植物物种丰富度沿海拔梯度呈现单峰格局造成的 影响是否显著, 我们对不做插值处理的 1,205 个物 种的物种丰富度海拔分布格局进行了研究, 发现物 种丰富度随海拔的上升呈先增后减的单峰格局(附 录13), 在海拔800-900 m范围内达到最高, 有145个 物种, 占西双版纳山地单一海拔记录物种的 $12.0 \%$ 。 二次拟合曲线 $\left(y=-3.93 \times 10^{-5} x^{2}+0.06 x+72.84, n=\right.$ $20, P<0.001$ )可解释物种丰富度 $51.2 \%$ 的变化, 说 明插值法对西双版纳山地植物物种丰富度沿海拔 梯度呈现单峰格局的影响并不显著。

\section{2 物种丰富度和物种密度的对比}

在等海拔间隔的梯度上, 每100 m高度带上的 面积可解释物种丰富度 $81.9 \%$ 的变化。因此, 面积对 物种丰富度的影响不容小觑, 在探索物种丰富度的 海拔格局及其成因机制时, 同时分析物种密度的海 拔格局及其潜在机制非常重要。本文发现幕函数种面积关系为西双版纳野生种子植物的最优拟合模 型, 这与以往的一些研究结果一致(McCain, 2007; 池秀莲和唐志尧, 2011)。但中 -面积关系具有许多模 型, 并且不同区域不同类群的最优模型存在差异
(Vetaas \& Grytnes, 2002; 王志恒等, 2004a; 冯建孟 等, 2006; 刘洋等, 2007)。因此，采用某个种一面积关 系模型计算多个山地植物群落的物种密度显然不 合理。假如采用每个山地每个植物类群的种-面积 关系最优模型独自计算物种密度，那么又存在不同 模型的生物学意义难以统一的问题。采用等面积高 度带计算物种密度较种-面积关系计算物种密度更 具优势, 可在实现物种密度计算体系标准化和一致 的前提下，对关于物种密度的不同来源的研究进行 对比分析和归纳综述。

Bachman等(2004)研究了世界最大的热带岛屿 New Guinea岛上棕榈科植物物种丰富度的垂直分 布格局，发现在等海拔间隔梯度上，物种丰富度呈 现单调递减的变化趋势, 然而在等面积海拔梯度上 呈现单峰格局。本文采用Bachman等(2004)将海拔 梯度划分为等面积高度带的方法，去除面积对物种 丰富度的影响。研究结果表明，无论沿等海拔间隔 梯度，还是沿等面积海拔梯度，西双版纳每个高度 带上的野生种子植物的物种个数都呈现单峰分布 格局, 且都在 $900 \mathrm{~m}$ 附近达到峰值。这与Bachman等 (2004)的研究结果不同, 这可能与New Guinea岛和 西双版纳的地形地貌特点不同有关。该岛每 $100 \mathrm{~m}$ 高度带的面积随海拔的上升呈单调递减，而西双版 纳每 $100 \mathrm{~m}$ 高度带的面积呈现随海拔上升先增加后 减少的单峰分布格局。本研究与朱源等(2007)对中 国贺兰山(海拔梯度从1,300 m到3,600 m)维管束植 物的研究结果类似。

\section{3 空缺分析}

空缺分析表明，西双版纳现有的自然保护区在 覆盖面积上远远不足以对全地区的种子植物进行 足够的保护。因此, 在西双版纳建立更多以野生种 子植物为保护对象的自然保护区或其他类型有效 保护地的需求非常迫切; 或者开展退耕还林、植被 恢复等生态补偿措施加强对保护空白地区的动植 物保护。本文保护空缺的分析可为西双版纳野生种 子植物资源和与植物密切相关的动物资源的保护 规划提供重要的理论依据。

致谢: 感谢中国科学院西双版纳热带植物园的朱华 老师提出的宝贵意见。感谢三位匿名审稿人和责任 编委对本文初稿提出宝贵意见和建议。 
参考文献

Acharya BK, Chettri B, Vijayan L (2011) Distribution pattern of trees along an elevation gradient of Eastern Himalaya, India. Acta Oecologica, 37, 329-336.

Adams JM, Woodward FI (1989) Patterns in tree species richness as a test of the glacial extinction hypothesis. Nature, 339, 699-701.

Allen AP, Brown JH, Gillooly JF (2002) Global biodiversity, biochemical kinetics, and the energetic-equivalence rule. Science, 297, 1545-1548.

Arrhenius O (1921) Species and area. Journal of Ecology, 9, 95-99.

Bachman S, Baker WJ, Brummitt N, Dransfield J, Moat J (2004) Elevational gradients, area and tropical island diversity: An example from the palms of New Guinea. Ecography, 27, 299-310.

Borcard D, Legendre P, Drapeau P (1992) Partialling out the spatial component of ecological variation. Ecology, 73, 1045-1055.

Brown JH, Gillooly JF, Allen AP, Savage VM, West GB (2004) Toward a metabolic theory of ecology. Ecology, 85, 1771-1789.

Chen J, Ban YF, Li SN (2014) China: Open access to earth land-cover map. Nature, 514, 434.

Chen J, Liao AP, Chen J, Peng S, Chen LJ, Zhang HW (2017) 30-meter global land cover data product-GlobeLand30. Geomatics World, 24, 1-8. (in Chinese with English abstract) [陈军, 廖安平, 陈晋, 彭舒, 陈利军, 张宏伟 (2017) 全球30 m地表覆盖遥感数据产品-GlobeLand30. 地理信息世界, 24, 1-8.]

Chi XL, Tang ZY (2011) Effects of area, temperature and geometric constraints on elevational patterns of species richness: A case study in the Mountain Taibai, Qinling Mountains, China. Chinese Journal of Plant Ecology, 35, 362-370. (in Chinese with English abstract) [池秀莲, 唐志 尧 (2011) 面积、温度及分布区限制对物种丰富度海拔格 局的影响: 以秦岭太白山为例. 植物生态学报, 35, 362-370.]

Clarke A, Gaston KJ (2006) Climate, energy and diversity. Proceedings of the Royal Society B: Biological Sciences, 273, 2257-2266.

Colwell RK (2008) RangeModel: Tools for exploring and assessing geometric constraints on species richness (the mid-domain effect) along transects. Ecography, 31, 4-7.

Colwell RK, Hurtt GC (1994) Nonbiological gradients in species richness and a spurious Rapoport effect. The American Naturalist, 144, 570-595.

Colwell RK, Lees DC (2000) The mid-domain effect: Geometric constraints on the geography of species richness. Trends in Ecology \& Evolution, 15, 70-76.

Colwell RK, Rahbek C, Gotelli NJ (2004) The mid-domain effect and species richness patterns: What have we learned so far? The American Naturalist, 163, E1-E23.

Currie DJ (1991) Energy and large-scale patterns of animaland plant-species richness. The American Naturalist, 137, 27-49.

Currie DJ, Paquin V (1987) Large-scale biogeographical patterns of species richness of trees. Nature, 329, 326-327.

Diniz-Filho JAF, Bini LM, Hawkins BA (2003) Spatial autocorrelation and red herrings in geographical ecology. Global Ecology and Biogeography, 12, 53-64.

Dobson AP (1997) Geographic distribution of endangered species in the United States. Science, 275, 550-553.

Evans KL, James NA, Gaston KJ (2006) Abundance, species richness and energy availability in the North American avifauna. Global Ecology and Biogeography, 15, 372-385.

Feng CG, Tong C, Zhang RY, Li GG, Wang HKY, Tang YT, Zhang CF, Zhao K (2017) Biodiversity and distribution patterns of Triplophysa species in the northeastern margin of the Tibetan Plateau. Biodiversity Science, 25, 53-61. (in Chinese with English abstract) [冯晨光, 童超, 张仁意, 李 国刚, 王贺崐元, 汤永涛, 张存芳, 赵凯 (2017) 青藏高 原东北部边缘高原鳅属鱼类的多样性与分布格局. 生物 多样性, 25, 53-61.]

Feng JM, Wang XP, Li J, Fang JY (2006) Effects of area and mid-domain effect on altitudinal pattern of seed plants richness in Lijiang, Yunnan, China. Biodiversity Science, 14, 107-113. (in Chinese with English abstract) [冯建孟, 王襄 平, 李晶, 方精云 (2006) 面积和中间膨胀效应对丽江地 区种子植物物种丰富度垂直分布格局的影响. 生物多样 性, 14, 107-113.]

Gillooly JF, Brown JH, West GB, Savage VM, Charnov EL (2001) Effects of size and temperature on metabolic rate. Science, 293, 2248-2251.

Grytnes JA, Beaman JH, Romdal TS, Rahbek C (2010) The mid-domain effect matters: Simulation analyses of range-size distribution data from Mount Kinabalu, Borneo. Journal of Biogeography, 35, 2138-2147.

Hawkins BA (2001) Ecology's oldest pattern? Trends in Ecology and Evolution, 16, 470.

Hawkins BA, DeVries PJ (2009) Tropical niche conservatism and the species richness gradient of North American butterflies. Journal of Biogeography, 36, 1698-1711.

Hawkins BA, Field R, Cornell HV, Currie DJ, Guegan JF, Kaufman DM, Kerr JT, Mittelbach GG, Oberdorff T, O’Brien EM, Porter EE, Turner JRG (2003) Energy, water, and broad-scale geographic patterns of species richness. Ecology, 84, 3105-3117.

He X, Du F, Yang YM, Yin WY, Zhuang CZ, Yan XS, Zhao MX (2011) Pattern of species richness along altitudinal gradient in Tongbiguan Nature Reserve, Southwest China and with a discussion on calculation methods of species density. Journal of Tropical and Subtropical Botany, 19, 543-548. (in Chinese with English abstract) [和霞, 杜凡, 杨宇明, 尹伍元, 庄翠珍, 岩香甩, 赵明旭 (2011) 铜壁关自然保 
护区种子植物物种丰富度的海拔梯度格局——兼论物种 密度的计算方法. 热带亚热带植物学报, 19, 543-548.]

Hijmans RJ, Cameron SE, Parra JL, Jones PG, Jarvis A (2005) Very high resolution interpolated climate surfaces for global land areas. International Journal of Climatology, 25, 1965-1978.

Jetz W, Rahbek C (2002) Geographic range size and determinants of avian species richness. Science, 297, 1548-1551.

Karger DN, Kluge J, Krömer T, Hemp A, Lehnert M, Kessler M (2011) The effect of area on local and regional elevational patterns of species richness. Journal of Biogeography, 38, 1177-1185.

Kati V, Devillers P, Dufr M, Vokou D, Lebrun P (2004) Hotspots, complementarity or representativeness? Designing optimal small-scale reserves for biodiversity conservation. Biological Conservation, 120, 471-480.

Lan GY, Hu YH, Cao M, Zhu H, Wang H, Zhou SX, Deng XB, Cui JY, Huang JG, Liu LY (2008) Establishment of Xishuangbanna tropical forest dynamics plot: Species compositions and spatial distribution patterns. Journal of Plant Ecology (Chinese Version), 32, 287-298. (in Chinese with English abstract) [兰国玉, 胡跃华, 曹敏, 朱华, 王洪, 周 仕顺, 邓晓保, 崔景云, 黄建国, 刘林云 (2008) 西双版 纳热带森林动态监测样地一一树种组成与空间分布格局. 植物生态学报, 32, 287-298.]

Li D, Tang JW, Luo CK, Li JS, Liu ZA (2006) Analysis on the coenological characteristics of monsoonal evergreen broad-leaved forest communities in Xishuangbanna. Journal of Mountain Science, 24, 257-267. (in Chinese with English abstract) [李冬, 唐建维, 罗成坤, 李俊松, 刘正安 (2006) 西双版纳季风常绿阔叶林的群落学特征. 山地学报, 24 , 257-267.]

Li DQ, Song YL (2000) Review on hot spot and GAP analysis. Chinese Biodiversity, 8, 208-214. (in Chinese with English abstract) [李迪强, 宋延龄 (2000) 热点地区与GAP分析 研究进展. 生物多样性, 8, 208-214.]

Li QY, Wang XP (2013) Elevational pattern of species richness in the Three Gorges region of the Yangtze River: Effect of climate, geometric constraints, area and topographical heterogeneity. Biodiversity Science, 21, 141-152. (in Chinese with English abstract) [李巧燕, 王襄平 (2013) 长江三峡 库区物种多样性的垂直分布格局: 气候、几何限制、面积 及地形异质性的影响. 生物多样性, 21, 141-152.]

Liu KM, Zheng Z, Gong DJ (2017) Elevational patterns of species richness and their underlying mechanism. Chinese Journal of Ecology, 36, 541-554. (in Chinese with English abstract) [刘开明, 郑智, 龚大洁 (2017) 物种丰富度的垂 直分布格局及其形成机制. 生态学杂志, 36, 541-554.]

Liu QF, Liu Y, Sun XL, Zhang XF, Kang SRL, Ding Y, Zhang Q, Niu JM (2015) The explanation of climatic hypotheses to community species diversity patterns in Inner Mongolia grasslands. Biodiversity Science, 23, 463-470. (in Chinese with English abstract) [刘庆福, 刘洋, 孙小丽, 张雪峰, 康
萨如拉, 丁勇, 张庆, 牛建明 (2015) 气候假说对内蒙古 草原群落物种多样性格局的解释. 生物多样性, 23, 463-470.]

Liu Y, Zhang YP, He DM, Cao M, Zhu H (2007) Elevational patterns of species richness and climate interpretation of longitudinal range-gorge region. Chinese Science Bulletin, 52, 43-50. (in Chinese) [刘洋, 张一平, 何大明, 曹敏, 朱 华 (2007) 纵向岭谷区山地植物物种丰富度垂直分布格 局及气候解释. 科学通报, 52, 43-50.]

Lomolino MV (2001) Elevation gradients of species-density: Historical and prospective views. Global Ecology \& Biogeography, 10, 3-13.

McCain CM (2007) Area and mammalian elevational diversity. Ecology, 88, 76-86.

Myers N (1988) Threatened biotas: "Hot spots" in tropical forests. Environmentalist, 8, 187-208.

Nogués-Bravo D, Araújo MB, Romdal T, Rahbek C (2008) Scale effects and human impact on the elevational species richness gradients. Nature, 453, 216-219.

O’Brien EM (1993) Climatic gradients in woody plant species richness: Towards an explanation based on an analysis of southern Africa's woody flora. Journal of Biogeography, 20, 181-198.

O’Brien EM (1998) Water-energy dynamics, climate, and prediction of woody plant species richness: An interim general model. Journal of Biogeography, 25, 379-398.

Pouteau R, Bayle É, Blanchard É, Birnbaum P, Cassan J, Hequet V, Ibanez T, Vandrot H (2015) Accounting for the indirect area effect in stacked species distribution models to map species richness in a montane biodiversity hotspot. Diversity \& Distributions, 21, 1329-1338.

Qian H (1998) Large-scale biogeographic patterns of vascular plant richness in North America: An analysis at the generic level. Journal of Biogeography, 25, 829-836.

Rahbek C (1997) The relationship among area, elevation, and regional species richness in neotropical birds. The American Naturalist, 149, 875-902.

Rahbek C (2005) The role of spatial scale and the perception of large-scale species-richness patterns. Ecology Letters, 8, 224-239.

Sanders NJ (2002) Elevational gradients in ant species richness: Area, geometry, and Rapoport's rule. Ecography, 25, 25-32.

Tang LL, Li TB, Li DW, Meng XX (2014) Elevational patterns of plant richness in the Taibai Mountain, China. The Scientific World Journal, 2014, 309053.

Vetaas OR, Grytnes JA (2002) Distribution of vascular plant species richness and endemic richness along the Himalayan elevation gradient in Nepal. Global Ecology \& Biogeography, 11, 291-301.

Wang ZH, Chen AP, Fang JY (2004a) Richness of seed plants in relation with topography in Hunan Province. Acta Geographica Sinica, 59, 889-894. (in Chinese with English ab- 
stract) [王志恒, 陈安平, 方精云 (2004a) 湖南省种子植 物物种丰富度与地形的关系. 地理学报, 59, 889-894.]

Wang ZH, Chen AP, Piao SL, Fang JY (2004b) Pattern of species richness along an altitudinal gradient on Gaoligong Mountains, Southwest China. Biodiversity Science, 12, 82-88. (in Chinese with English abstract) [王志恒, 陈安平, 朴世龙, 方精云 (2004b) 高黎贡山种子植物物种丰富度 沿海拔梯度的变化. 生物多样性, 12, 82-88.]

Wang ZH, Tang ZY, Fang JY (2007) Altitudinal patterns of seed plant richness in the Gaoligong Mountains, south-east Tibet, China. Diversity \& Distributions, 13, 845-854.

Wang ZH, Tang ZY, Fang JY (2009a) The species-energy hypothesis as a mechanism for species richness patterns. Biodiversity Science, 17, 613-624. (in Chinese with English abstract) [王志恒, 唐志尧, 方精云 (2009a) 物种多样性 地理格局的能量假说. 生物多样性, 17, 613-624.]

Wang ZH, Tang ZY, Fang JY (2009b) Metabolic theory of ecology: An explanation for species richness patterns based on the metabolic processes of organisms. Biodiversity Science, 17, 625-634. (in Chinese with English abstract) [王 志恒, 唐志尧, 方精云 (2009b) 生态学代谢理论：基于 个体新陈代谢过程解释物种多样性的地理格局. 生物多 样性, 17, 625-634.]

Wen C, Gu L, Wang H, Lü Z, Hu RC, Zhong J (2015) GAP analysis on national nature reserves in China based on the distribution of endangered species. Biodiversity Science, 23, 591-600. (in Chinese with English abstract) [闻丞, 顾垒, 王昊，吕植，胡若成，钟嘉 (2015) 基于最受关注濒危物 种分布的国家级自然保护区空缺分析. 生物多样性, 23, 591-600.]

Woodward FI, Lomas MR, Kelly CK (2004) Global climate and the distribution of plant biomes. Philosophical Transactions of the Royal Society B: Biological Sciences, 359, 1465-1476.

Xu X, Zhang HY, Luo J, Zhang DJ, Ma A (2017) Area-corrected species richness patterns of vascular plants along a tropical elevational gradient. Journal of Mountain Science, 14, 694-704.

Zhang YB, Du HD, Jin XH, Ma KP (2015) Species diversity and geographic distribution of wild Orchidaceae in China. Chinese Science Bulletin, 60, 179-188. (in Chinese) [张殷
波, 杜吴东, 金效华, 马克平 (2015) 中国野生兰科植物 物种多样性与地理分布. 科学通报, 60, 179-188.]

Zhang ZJ, Yan YJ, Tian Y, Li JS, He JS, Tang ZY (2015) Distribution and conservation of orchid species richness in China. Biological Conservation, 181, 64-72.

Zheng Z, Gong DJ, Zhang Q, Zhao HB (2014) Vertical patterns of plant species diversity in the Baishuijiang Nature Reserve: Explanation of area, climate and boundary constraint. Chinese Journal of Applied Ecology, 25, 3390-3398. (in Chinese with English abstract) [郑智, 龚大洁, 张乾, 赵海 斌 (2014) 白水江自然保护区植物物种多样性的垂直格 局: 面积、气候、边界限制的解释. 应用生态学报, 25, 3390-3398.]

Zhu $\mathrm{H}$ (2007) On the classification of forest vegetation in Xishuangbanna, southern Yunnan. Acta Botanica Yunnanica, 29, 377-387. (in Chinese with English abstract) [朱华 (2007) 论滇南西双版纳的森林植被分类. 云南植物研究, 29, 377-387.]

Zhu H (2006) A discussion on plant diversity of tropical montane rain forests in Xishuangbanna, Yunnan. Journal of Plant Ecology (Chinese Version), 30, 184-186. (in Chinese with English abstract) [朱华 (2006) 西双版纳热带山地雨林的 植物多样性研究的一些问题讨论. 植物生态学报, 30, 184-186.]

Zhu H, Wang H, Li BG, Zhou SX, Zhang JH (2015) Studies on the forest vegetation of Xishuangbanna. Plant Science Journal, 33, 641-726. (in Chinese with English abstract) [朱华, 王洪, 李保贵, 周仕顺, 张建侯 (2015) 西双版纳森林植 被研究. 植物科学学报, 33, 641-726.]

Zhu H, Yan LC (2012) Native Seed Plants in Xishuangbanna of Yunnan. Science Press, Beijing. (in Chinese) [朱华, 间丽春 (2012) 云南西双版纳野生种子植物. 科学出版社, 北京.]

Zhu Y, Jiang Y, Liu QR, Xiong M, Kang MY (2007) Altitudinal pattern of vascular plant species richness based on equal-area belts in Mt. Helan. Biodiversity Science, 15, 408-418. (in Chinese with English abstract) [朱源, 江源, 刘全儒, 熊敏, 康慕谊 (2007) 基于等面积高度带划分的 贺兰山维管植物物种丰富度的海拔分布格局. 生物多样 性, 15, 408-418.]

(责任编委: 王志恒 责任编辑: 黄祥忠)

\section{附录 Supplementary Material}

附录1 西双版纳种子植物种-面积关系4种模型的回归分析

Appendix 1 Four regression models of species-area relationships for seed plants in Xishuangbanna http://www.biodiversity-science.net/fileup/PDF/2017132-1.pdf

附录2 基于等面积划分的高度带海拔起止范围(m)

Appendix 2 Maximumal and minimumal elevation values of equal-area elevational bands (m) http://www.biodiversity-science.net/fileup/PDF/2017132-2.pdf 
附录3 西双版纳面积、中域效应模拟值、年均温、年降水量、最冷月最低温和实际蒸散量的垂直分布格局

Appendix 3 Elevational patterns of area, species richness predicted by mid-domain effect, mean annual temperature, mean annual precipitation, minimum temperature of coldest month and actual evapotranspiration in Xishuangbanna

http://www.biodiversity-science.net/fileup/PDF/2017132-3.pdf

附录4 西双版纳种子植物物种丰富度与解释因子的回归分析结果

Appendix 4 Regression analyses between species richness and explanatory variables for seed plants in Xishuangbanna http://www.biodiversity-science.net/fileup/PDF/2017132-4.pdf

附录5 面积、中域效应和水热气候对西双版纳种子植物物种丰富度海拔格局的相对解释量 $(\%)$

Appendix 5 Relative explanatory power (\%) of area, mid-domain effect and climatic factors for the elevational pattern of seed plant species richness in Xishuangbanna

http://www.biodiversity-science.net/fileup/PDF/2017132-5.pdf

附录6 西双版纳种子植物物种密度 $I$ 与海拔、中域效应模拟值、年均温、年降水量、最冷月最低温和实际蒸散量的关系 Appendix 6 Relationship between species density $I$ of seed plants and elevation, species density predicted by mid-domain effect, mean annual temperature, mean annual precipitation, minimum temperature of coldest month and actual evapotranspiration in $\mathrm{Xi}-$ shuangbanna

http://www.biodiversity-science.net/fileup/PDF/2017132-6.pdf

\section{附录7 西双版纳种子植物物种密度 $I$ 与解释因子的回归分析结果}

Appendix 7 Regression analyses between species density and explanatory variables for seed plants in Xishuangbanna http://www.biodiversity-science.net/fileup/PDF/2017132-7.pdf

附录8 西双版纳种子植物物种密度 $\boldsymbol{I}_{20}$ 与海拔、中域效应模拟值、年均温、年降水量、最冷月最低温和实际蒸散量的关系 Appendix 8 Relationship between species density $I_{20}$ of seed plants and elevation, species density predicted by mid-domain effect, mean annual temperature, mean annual precipitation, minimum temperature of coldest month and actual evapotranspiration in Xishuangbanna http://www.biodiversity-science.net/fileup/PDF/2017132-8.pdf

附录9 西双版纳种子植物物种密度 $\boldsymbol{I}_{20}$ 与解释因子的回归分析结果

Appendix 9 Regression analyses between species density $I_{20}$ and explanatory variables for seed plants in Xishuangbanna http://www.biodiversity-science.net/fileup/PDF/2017132-9.pdf

附录10 不同空间距离上物种丰富度和模型残差的Moran's I指数

Appendix 10 Moran's $I$ of species richness and model residuals at different distances http://www.biodiversity-science.net/fileup/PDF/2017132-10.pdf

附录11 不同空间距离上物种密度 $I$ 和模型残差的Moran's I指数

Appendix 11 Moran's $I$ of species density $I$ and model residuals at different distances http://www.biodiversity-science.net/fileup/PDF/2017132-11.pdf

附录12 不同空间距离上物种密度 $I_{20}$ 和模型残差的Moran's I指数

Appendix 12 Moran's $I$ of species density $I_{20}$ and model residuals at different distances http://www.biodiversity-science.net/fileup/PDF/2017132-12.pdf

附录13 西双版纳山地单一海拔记录物种的物种丰富度沿海拔梯度的分布格局

Appendix 13 The elevational pattern of species richness for a seed plant species set (species with only a single elevation record) in Xishuangbanna

http://www.biodiversity-science.net/fileup/PDF/2017132-13.pdf 
徐翔, 张化永, 谢婷, 孙青青, 田永兰. 西双版纳种子植物物种多样性的垂直格局及机制. 生物多样 性, 2018, 26 (7): 678-689.

http://www.biodiversity-science.net/CN/10.17520/biods.2017132

附录 1 西双版纳种子植物种一面积关系 4 种模型的回归分析

2 Appendix 1 Four regression models of species-area relationships for seed plants in Xishuangbanna

\begin{tabular}{lllllr}
\hline 因变量 & 自变量 & 斜率 & 截距 & $r^{2}$ & \multicolumn{2}{c}{$\begin{array}{c}\text { 赤池信息量 } \\
\text { Resplanatory variable }\end{array}$} & Slope & Intercept & & $\begin{array}{c}\text { 准则 } \\
\text { AIC }_{C}\end{array}$ \\
\hline 物种丰富度 Species richness & 面积 Area & $1.06^{* *}$ & $167.10^{\mathrm{ns}}$ & $0.848^{* *}$ & 286.21 \\
物种丰富度 Species richness & $\log$ (面积) $\log$ (Area) & $258.49^{* *}$ & $-516.44^{*}$ & $0.702^{* *}$ & 299.67 \\
$\log$ (物种丰富度) $\log$ (species richness) & 面积 Area & $0.002^{* *}$ & $4.25^{* *}$ & $0.614^{* *}$ & 68.242 \\
$\log$ (物种丰富度) $\log$ (species richness) & $\log$ (面积) $\log$ (Area) & $0.75^{* *}$ & $1.87^{* *}$ & $0.819^{* *}$ & 53.127 \\
\hline
\end{tabular}

${ }^{*} P<0.05 ;{ }^{* *} P<0.001 ;$ ns, 不显著 non-significant.

4

6 
徐翔, 张化永, 谢婷, 孙青青, 田永兰. 西双版纳种子植物物种多样性的垂直格局及机制. 生物多样 性, 2018, 26 (7): 678-689.

http://www.biodiversity-science.net/CN/10.17520/biods.2017132

18 附录2 基于等面积划分的高度带海拔起止范围(m)

Appendix 2 Maximumal and minimumal elevation values of equal-area elevational bands (m)

\begin{tabular}{ll|l|ll}
\hline 序号 & $\begin{array}{l}20 \text { 等分 } \\
20 \text { elevational bands }\end{array}$ & $\begin{array}{l}\text { 序号 } \\
\text { No. of bands }\end{array}$ & $\begin{array}{l}20 \text { 等分 } \\
20 \text { elevational bands }\end{array}$ \\
\hline 1 & $414.0-658.2$ & 11 & $1,124.4-1,163.4$ \\
2 & $658.2-723.3$ & & 12 \\
3 & $723.3-786.0$ & & $1,163.4-1,201.7$ \\
13 & $1,201.7-1,241.5$ \\
4 & $786.0-848.6$ & 15 & $1,241.5-1,284.8$ \\
5 & $848.6-907.6$ & 16 & $1,284.8-1,334.3$ \\
6 & $907.6-958.4$ & 17 & $1,334.3-1,392.8$ \\
7 & $958.4-1,003.3$ & 18 & $1,392.8-1,468.2$ \\
8 & $1,003.3-1,045.1$ & 19 & $1,468.2-1,569.4$ \\
9 & $1,045.1-1,085.3$ & 20 & $1,569.4-1,707.1$ \\
10 & $1,085.3-1,124.4$ & & $1,707.1-2,428.0$ \\
\hline
\end{tabular}


徐翔, 张化永, 谢婷, 孙青青, 田永兰. 西双版纳种子植物物种多样性的垂直格局及机制. 生物多样 性, 2018, 26 (7): 678-689.

http://www.biodiversity-science.net/CN/10.17520/biods.2017132
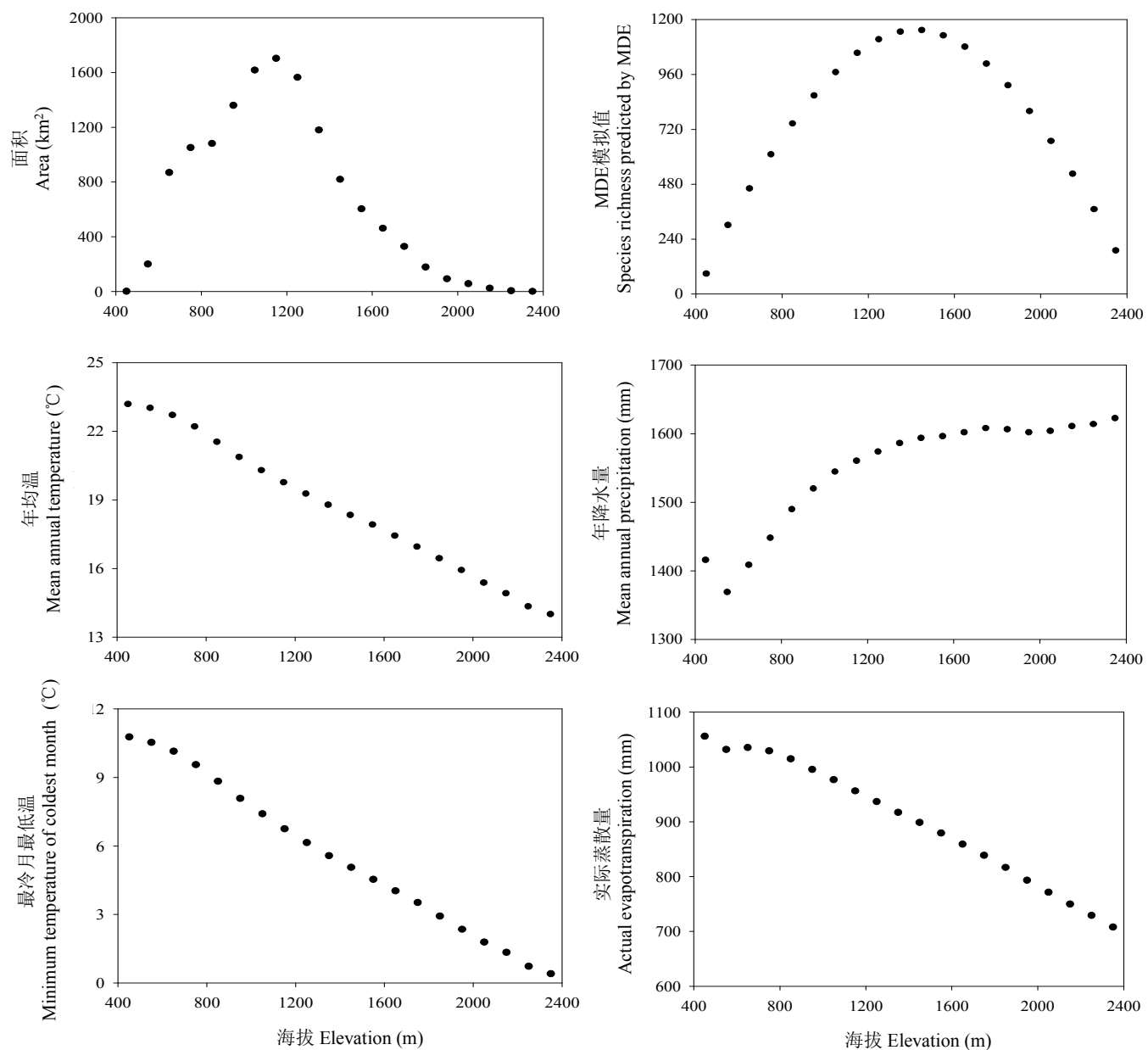

附录 3 西双版纳面积、中域效应模拟值、年均温、年降水量、最冷月最低温和实际蒸散量的垂直分 布格局

Appendix 3 Elevational patterns of area, species richness predicted by mid-domain effect, mean annual temperature, mean annual precipitation, minimum temperature of coldest month and actual evapotranspiration in Xishuangbanna 
徐翔, 张化永, 谢婷, 孙青青, 田永兰. 西双版纳种子植物物种多样性的垂直格局及机制. 生物多样 性, 2018, 26 (7): 678-689.

http://www.biodiversity-science.net/CN/10.17520/biods.2017132

附录 4 西双版纳种子植物物种丰富度与解释因子的回归分析结果

28 Appendix 4 Regression analyses between species richness and explanatory variables for seed plants in Xishuangbanna

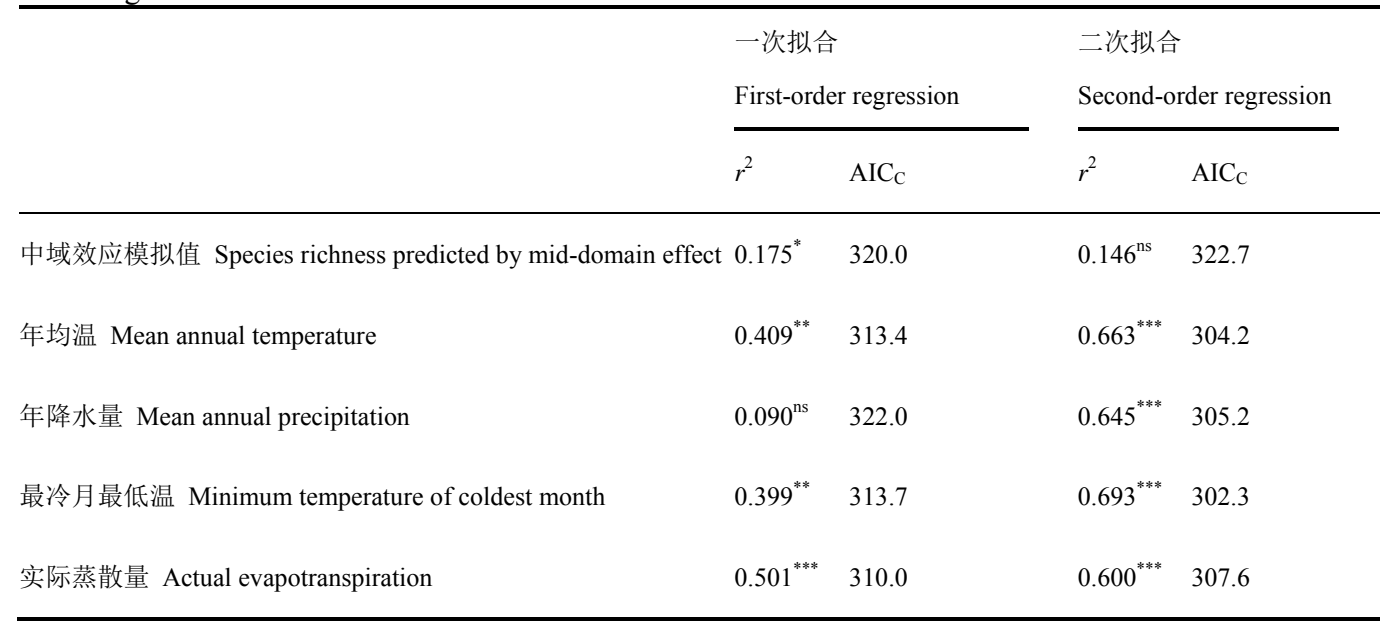

${ }^{*} P<0.05 ;{ }^{* *} P<0.01 ;{ }^{* * *} P<0.001 ;$ ns, 不显著 non-significant. 
徐翔, 张化永, 谢婷, 孙青青, 田永兰. 西双版纳种子植物物种多样性的垂直格局及机制. 生物多样 性, 2018, 26 (7): 678-689.

http://www.biodiversity-science.net/CN/10.17520/biods.2017132

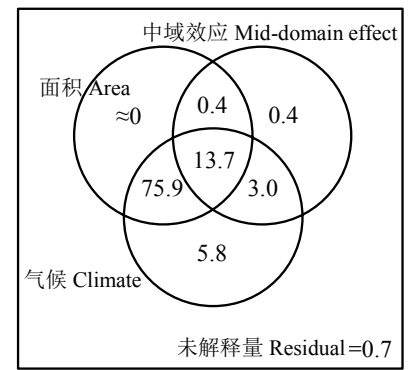

附录 5 面积、中域效应和水热气候对西双版纳种子植物物种丰富度海拔格局的相对解释量 $(\%)$

48 Appendix 5 Relative explanatory power (\%) of area, mid-domain effect and climatic factors for the elevational pattern of seed plant species richness in Xishuangbanna 
徐翔, 张化永, 谢婷, 孙青青, 田永兰. 西双版纳种子植物物种多样性的垂直格局及机制. 生物多样 性, 2018, 26 (7): 678-689.

http://www.biodiversity-science.net/CN/10.17520/biods.2017132
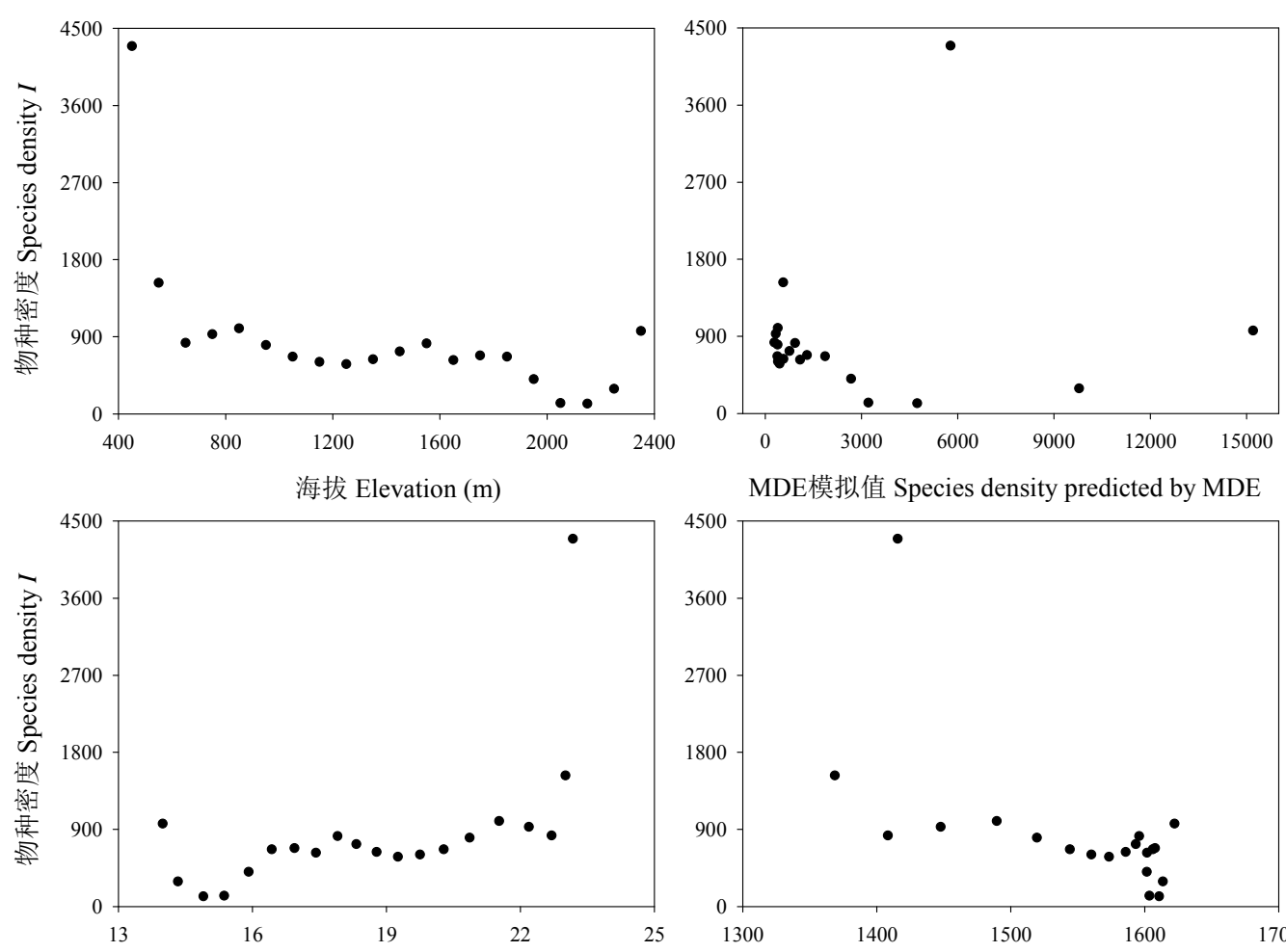

MDE模拟值 Species density predicted by MDE
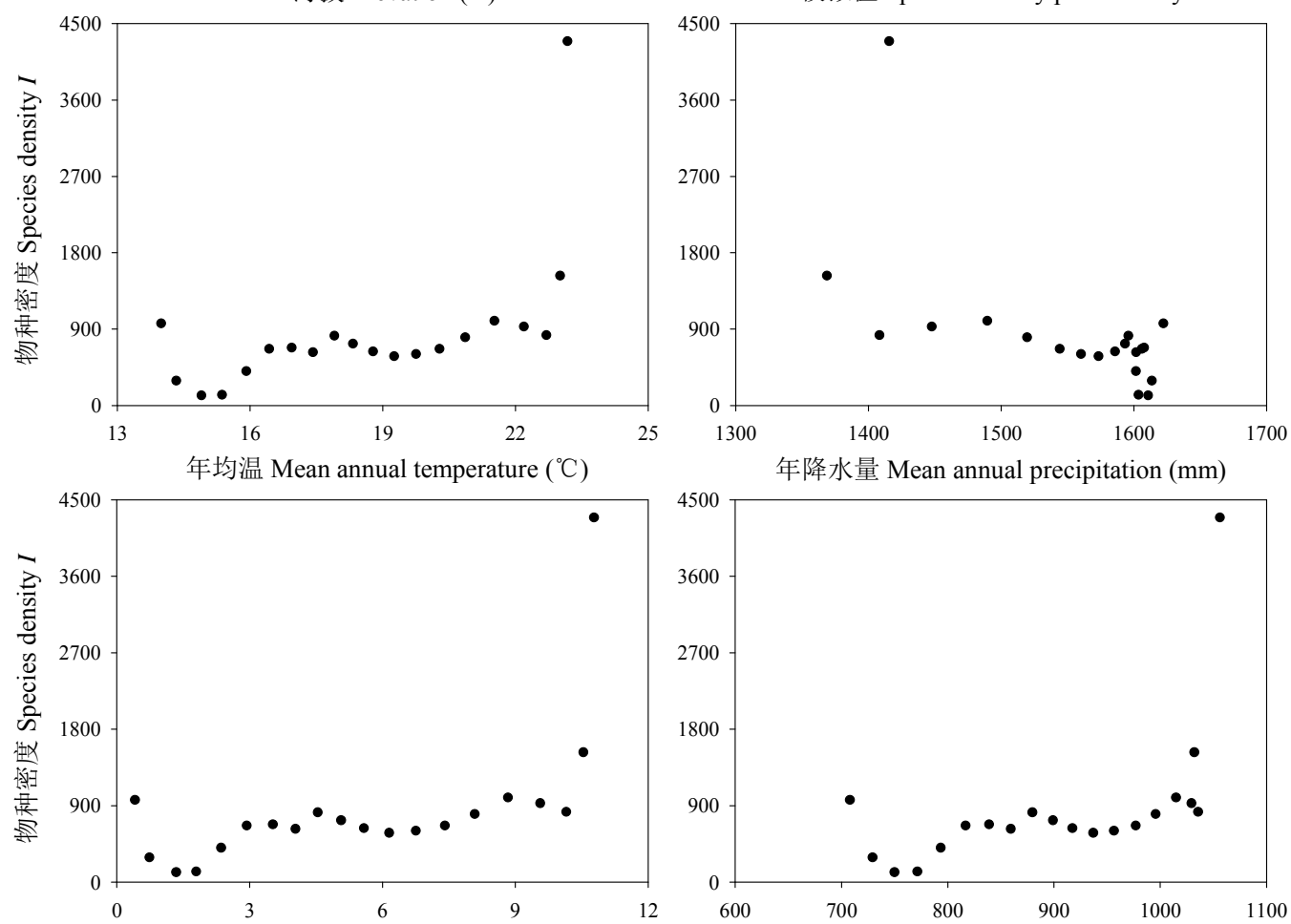

最冷月最低温 Minimum temperature of coldest month $\left({ }^{\circ} \mathrm{C}\right)$

实际蒸散量 Actual evapotranspiration (mm)

附录 6 西双版纳种子植物物种密度 $I$ 与海拔、中域效应模拟值、年均温、年降水量、最冷月最低温 52 和实际蒸散量的关系

Appendix 6 Relationship between species density $I$ of seed plants and elevation, species density predicted

54 by mid-domain effect, mean annual temperature, mean annual precipitation, minimum temperature of 56 coldest month and actual evapotranspiration in Xishuangbanna 
徐翔, 张化永, 谢婷, 孙青青, 田永兰. 西双版纳种子植物物种多样性的垂直格局及机制. 生物多样 性, 2018, 26 (7): 678-689.

http://www.biodiversity-science.net/CN/10.17520/biods.2017132

58 附录 7 西双版纳种子植物物种密度 $I$ 与解释因子的回归分析结果

\begin{tabular}{|c|c|c|c|c|}
\hline & \multicolumn{2}{|c|}{$\begin{array}{l}\text { 一次拟合 } \\
\text { First-order regression }\end{array}$} & \multicolumn{2}{|c|}{$\begin{array}{l}\text { 二次拟合 } \\
\text { Second-order regression }\end{array}$} \\
\hline & $r^{2}$ & $\mathrm{AIC}_{\mathrm{C}}$ & $r^{2}$ & $\overline{\mathrm{AIC}_{\mathrm{C}}}$ \\
\hline \multicolumn{2}{|c|}{ 中域效应模拟值 Species density predicted by mid-domain effect $0^{\text {ns }}$} & 333.5 & $0^{\mathrm{ns}}$ & 336.0 \\
\hline 年均温 Mean annual temperature & $0.277^{* *}$ & 326.2 & $0.395^{* *}$ & 324.7 \\
\hline 年降水量 Mean annual precipitation & $0.326^{* *}$ & 324.8 & $0.290^{*}$ & 327.9 \\
\hline 最冷月最低温 Minimum temperature of coldest month & $0.286^{* *}$ & 326.0 & $0.406^{* *}$ & 324.3 \\
\hline 实际蒸散量 Actual evapotranspiration & $0.232^{*}$ & 327.4 & $0.367^{* *}$ & 325.6 \\
\hline
\end{tabular}

${ }^{*} P<0.05 ;{ }^{* *} P<0.01 ;{ }^{* * *} P<0.001 ;$ ns, 不显著 non-significant. 
徐翔, 张化永, 谢婷, 孙青青, 田永兰. 西双版纳种子植物物种多样性的垂直格局及机制. 生物多样 性, 2018, 26 (7): 678-689.

http://www.biodiversity-science.net/CN/10.17520/biods.2017132
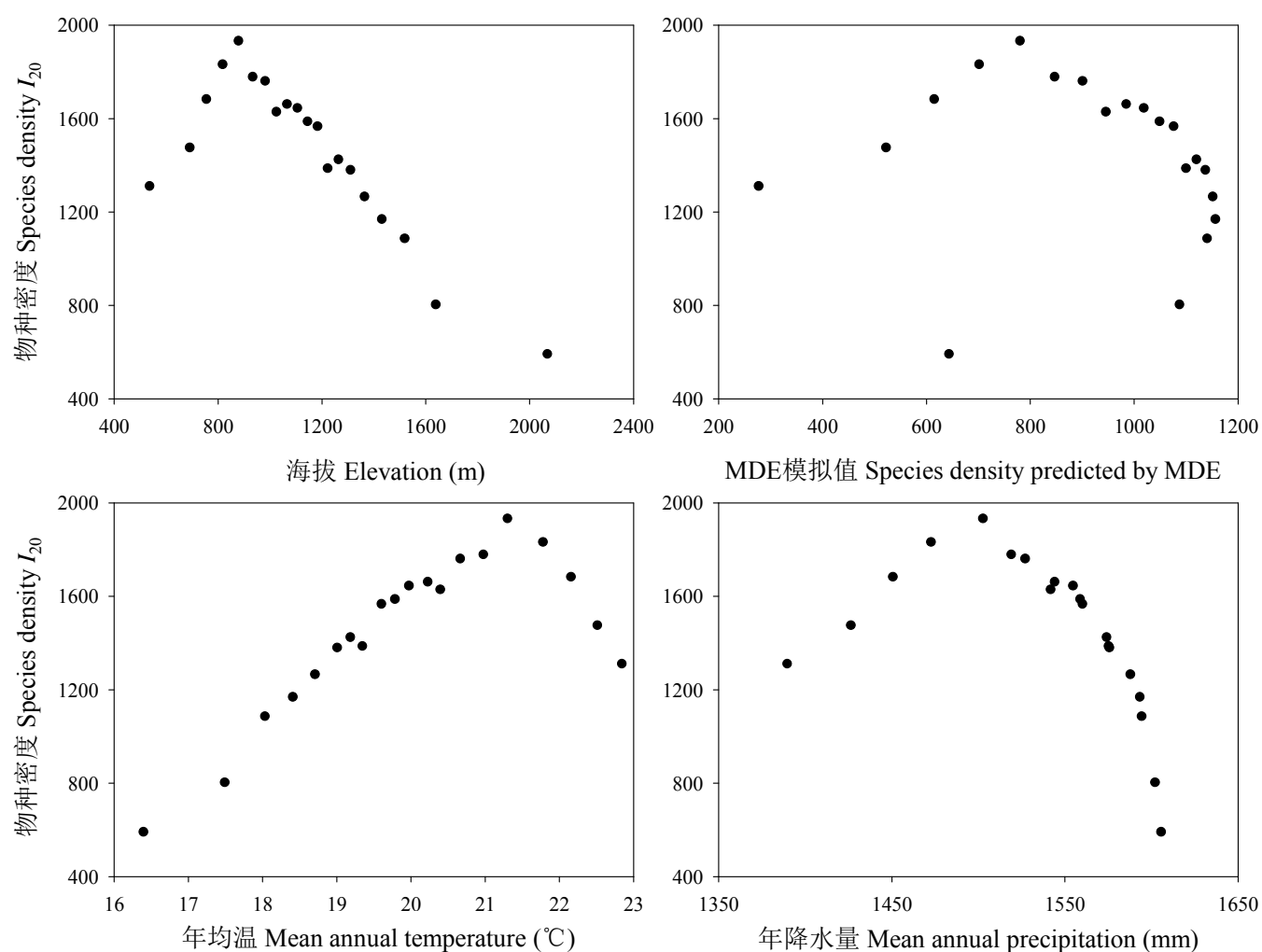

MDE模拟值 Species density predicted by MDE
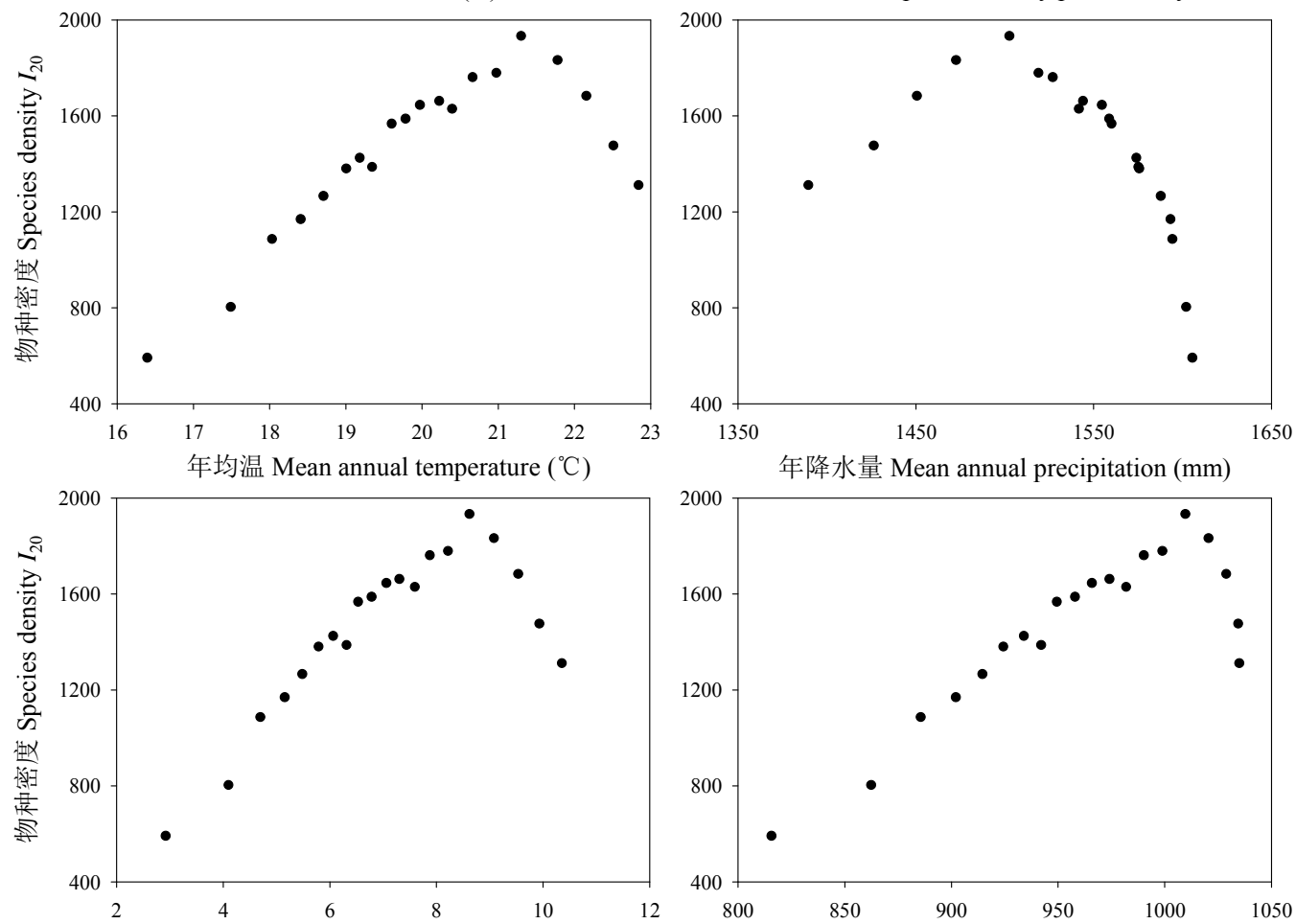

最冷月最低温 Minimum temperature of coldest month $\left({ }^{\circ} \mathrm{C}\right)$

实际蒸散量 Actual evapotranspiration (mm)

附录 8 西双版纳种子植物物种密度 $I_{20}$ 与海拔、中域效应模拟值、年均温、年降水量、最冷月最低 64 温和实际蒸散量的关系

Appendix 8 Relationship between species density $I_{20}$ of seed plants and elevation, species density predicted by mid-domain effect, mean annual temperature, mean annual precipitation, minimum temperature of coldest month and actual evapotranspiration in Xishuangbanna 
徐翔, 张化永, 谢婷, 孙青青, 田永兰. 西双版纳种子植物物种多样性的垂直格局及机制. 生物多样 性, 2018, 26 (7): 678-689.

http://www.biodiversity-science.net/CN/10.17520/biods.2017132

70 附录 9 西双版纳种子植物物种密度 $I_{20}$ 与解释因子的回归分析结果

Appendix 9 Regression analyses between species density $I_{20}$ and explanatory variables for seed plants in

72 Xishuangbanna

\begin{tabular}{|c|c|c|c|c|}
\hline & \multicolumn{2}{|c|}{$\begin{array}{l}\text { 一次拟合 } \\
\text { First-order regression }\end{array}$} & \multicolumn{2}{|c|}{$\begin{array}{l}\text { 二次拟合 } \\
\text { Second-order regression }\end{array}$} \\
\hline & $r^{2}$ & $\mathrm{AIC}_{\mathrm{C}}$ & $r^{2}$ & $\mathrm{AIC}_{\mathrm{C}}$ \\
\hline \multicolumn{5}{|c|}{ 中域效应模拟值 Species density predicted by mid-domain } \\
\hline & $0^{\mathrm{ns}}$ & 296.3 & $0.103^{\mathrm{ns}}$ & 295.4 \\
\hline \multicolumn{5}{|l|}{ effect } \\
\hline 年均温 Mean annual temperature & $0.539^{* * *}$ & 280.0 & $0.873^{* * *}$ & 256.3 \\
\hline 年降水量 Mean annual precipitation & $0.198^{*}$ & 291.1 & $0.899^{* * *}$ & 251.7 \\
\hline 最冷月最低温 Minimum temperature of coldest month & $0.543^{* * *}$ & 279.8 & $0.883^{* * *}$ & 254.6 \\
\hline 实际蒸散量 Actual evapotranspiration & $0.684^{* * *}$ & 272.5 & $0.816^{* * *}$ & 263.7 \\
\hline
\end{tabular}

74

76

78

80

82

84

86 
徐翔，张化永，谢婷，孙青青，田永兰. 西双版纳种子植物物种多样性的垂直格局及机制. 生物多样 性, 2018, 26 (7): 678-689.

http://www.biodiversity-science.net/CN/10.17520/biods.2017132

88

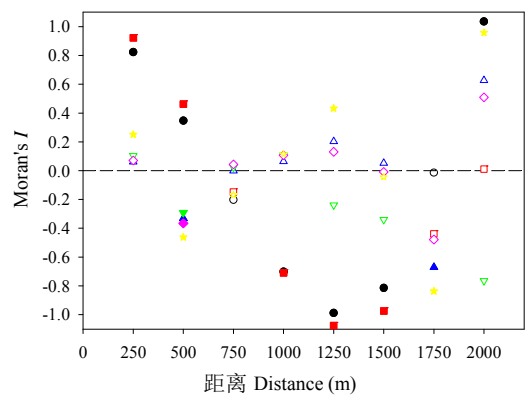

○物种丰富度 Species richness

$\square$ 物种丰富度与中域效应回归模型的残差Residual for the relationship between species richness and mid-domain effect

$\Delta$ 物种丰富度与年均温回归模型的残差 Residual for the relationship between species richness and mean annual temperature

$\nabla$ 物种丰富度与年降水量回归模型的残差 Residual for the relationship between species richness and mean annual precipitation

$\diamond$ 物种丰富度与最冷月最低温回归模型的残差 Residual for the relationship between species richness and minimum temperature of coldest month

物种丰富度与实际蒸散量回归模型的残差 Residual for the relationship between species richness and actual evapotranspiration

90 附录 10 不同空间距离上物种丰富度和模型残差的 Moran's $I$ 指数

92

Appendix 10 Moran's I of species richness and model residuals at different distances 
徐翔，张化永，谢婷，孙青青，田永兰. 西双版纳种子植物物种多样性的垂直格局及机制. 生物多样 性, 2018, 26 (7): 678-689.

http://www.biodiversity-science.net/CN/10.17520/biods.2017132

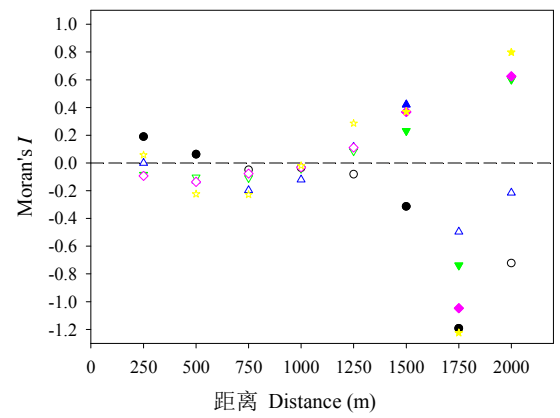

○物种密度 Species density

$\Delta$ 物种密度与年均温回归模型的残差 Residual for the relationship between species density and mean annual temperature

$\nabla$ 物种密度与年降水量回归模型的残差 Residual for the relationship between species density and mean annual precipitation

$\diamond$ 物种密度与最冷月最低温回归模型的残差 Residual for the relationship between species density and minimum temperature of coldest month

物种密度与实际蒸散量回归模型的残差 Residual for the relationship between species density and actual evapotranspiration

\section{8 附录 11 不同空间距离上物种密度 $I$ 和模型残差的 Moran's $I$ 指数}

Appendix 11 Moran's $I$ of species density $I$ and model residuals at different distances 
徐翔，张化永，谢婷，孙青青，田永兰. 西双版纳种子植物物种多样性的垂直格局及机制. 生物多样 性, 2018, 26 (7): 678-689.

http://www.biodiversity-science.net/CN/10.17520/biods.2017132

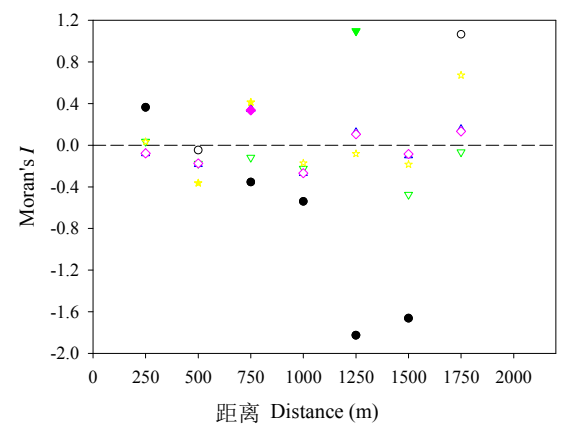

○物种密度 Species density

$\Delta$ 物种密度与年均温回归模型的残差 Residual for the relationship between species density and mean annual temperature

$\nabla$ 物种密度与年降水量回归模型的残差 Residual for the relationship between species density and mean annual precipitation

$\diamond$ 物种密度与最冷月最低温回归模型的残差 Residual for the relationship between species density and minimum temperature of coldest month

物种密度与实际蒸散量回归模型的残差 Residual for the relationship between species density and actual evapotranspiration

\section{8 附录 12 不同空间距离上物种密度 $I_{20}$ 和模型残差的 Moran's $I$ 指数}

Appendix 12 Moran's $I$ of species density $I_{20}$ and model residuals at different distances

130

132 
徐翔, 张化永, 谢婷, 孙青青, 田永兰. 西双版纳种子植物物种多样性的垂直格局及机制. 生物多样 性, 2018, 26 (7): 678-689.

http://www.biodiversity-science.net/CN/10.17520/biods.2017132

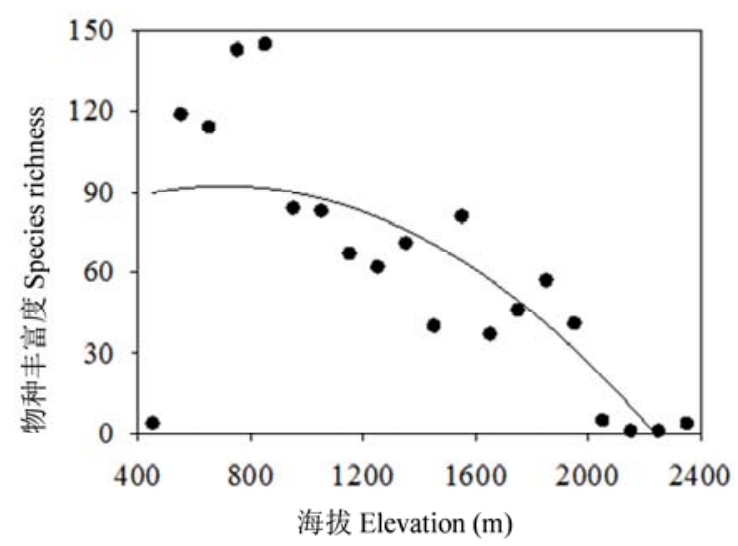

142 附录 13 西双版纳山地单一海拔记录物种的物种丰富度沿海拔梯度的分布格局

144 Appendix 13 The elevational pattern of species richness for a seed plant species set (species with only a 144 single elevation record) in Xishuangbanna 